\title{
Blair Disease? \\ Business Careers of the Former Democratic Heads of State and Government
}

\author{
Alexander Baturo \\ Dublin City University \\ Glasnevin, Dublin 9 \\ Dublin, Ireland \\ 353 (0) 17006475 \\ alex.baturo@dcu.ie
}

\author{
Slava Mikhaylov \\ University College London \\ 29/31 Tavistock Sq., \\ London, UK \\ 44 (0) 2076794725 \\ s.mikhaylov@ucl.ac.uk
}

\begin{abstract}
Despite the importance of the "revolving door" problem for democratic accountability, we lack systematic knowledge about business careers of former national leaders. Examining the careers of democratic heads of state and government from 1960-2010, we find that one in every seven turns to the private sector after office. Distinguishing between the factors that attract leaders to business and those that render leaders attractive, we find that personal background, such as prior business career and finance ministry portfolio as well as economic inequality and cultural norms, matter. We also find that economic growth and reduction in state spending during tenure contribute to the explanation. Furthermore, low policy constraints on leaders who preside over spending reduction or growth in office have little impact on the probability of their future careers. This favors the explanation that the private sector employs those former leaders only perceived as responsible, not those who implement policies with future careers in mind.
\end{abstract}

Key Words: Leadership, career concerns, welfare state, political economy 


\begin{abstract}
Despite the importance of the "revolving door" problem for democratic accountability, we lack systematic knowledge about business careers of former national leaders. Examining the careers of democratic heads of state and government from 1960-2010, we find that one in every seven turns to the private sector after office. Distinguishing between the factors that attract leaders to business and those that render leaders attractive, we find that the global CEO compensation rates, cultural norms, having served in office in Anglo-Saxon countries as well as their personal background, matter. We also find that certain economic outcomes and policies in office such as economic growth and reduction in state spending are often associated with post-tenure business careers. We do not find evidence, however, that leaders are able to implement policies with future careers in mind that would in turn raise concerns over accountability.
\end{abstract}

Key Words: Leadership, revolving door, career concerns, political economy 
Shortly after leaving the presidency, Nicolas Sarkozy of France (2007-2012), who was reportedly able to develop close links with the global financial sector while in office, embarked on a project to attract finance for his own private equity fund. Sarkozy's example, however, represents a larger phenomenon, aptly dubbed by Simon Kuper of Financial Times as the "Blair Disease" - a propensity of former democratic politicians, e.g., Blair in the UK, Schröder in Germany or Clinton in the USA — to work for the private sector after leaving office. ${ }^{1}$ Despite significant media attention to the links between private interests and politicians, their prior careers and careers after leaving office, ${ }^{2}$ we know surprisingly little about the business careers of former heads of state and government and whether such careers should be a cause for concern over democratic accountability.

Scholarship exists about leaders' policies in office and fate, particularly in non-democracies (e.g., Bueno de Mesquita et al., 2003; Goemans, 2008), but we lack systematic analyses of the fate and careers of former democratic leaders. Scholars have also long studied the financial returns of political office (e.g., Diermeier, Keane and Merlo, 2005; Eggers and Hainmueller, 2009). Such returns often accrue to actors once they leave politics and seek private sector employment in retirement, typically described as the "revolving doors" phenomenon (e.g., Blanes i Vidal, Draca and Fons-Rosen, 2012; Hillman, 2005). There is considerable body of knowledge about business careers of former public officials from various

${ }^{1}$ See Simon Kuper, "Another Outbreak of Blair Disease," Financial Times Magazine, 21 March 2014. On Sarkozy, see Anne-Sylvaine Chassany and Camilla Hall (2013) "Nicolas Sarkozy's Road from the Elysee to Private Equity”, Financial Times, 28 March 2013.

${ }^{2}$ For example, Prime-Minister Mario Monti of Italy (2011-13), the author of ambitious austerity measures, was a former senior advisor to Goldman Sachs, similar to several European leaders and top civil servants. See Stephen Foley, "What Price the New Democracy? Goldman Sachs Conquers Europe”, The Independent, 18 November 2011. 
branches and levels of government: former legislators (Bertrand, Bombardini and Trebbi, 2014; Blanes i Vidal, Draca and Fons-Rosen, 2012; Diermeier, Keane and Merlo, 2005; Eggers and Hainmueller, 2009), governmental staffers (Blanes i Vidal, Draca and Fons-Rosen, 2012), cabinet ministers (Etzion and Davis, 2008), governmental regulators (Cohen, 1986), and EU commissioners (Vaubel, Klingen and Muller, 2011). While qualitative studies exist about revolving door and careers of former national political leaders (e.g., Schweizer, 2015), there is still a lack of systematic comparative analyses of "revolving door" at the highest level of political leadership: among the former heads of state and government. We find that in the period 1960-2010, 75 former democratic national political leaders, or one in every seven among those who departed from office and did not fully retire from public life, pursued private sector employment, such as business consulting, law practice, corporate employment and board membership. Given the high public profile of former national leaders and the likely reputational costs associated with their business activities, what individual or structural factors explain their post-tenure careers?

The aim of the paper is twofold. First, drawing on existing literature on "revolving doors", career concerns, and political leadership, we systematically examine the determinants of private sector employment of former democratic heads of state and government in comparative perspective. We find that former politicians are more likely to turn to the private sector when they hail from Anglo-Saxon countries as well as when they have had prior business careers. Likewise, other factors, - i.e., when existing cultural norms are pro-business and when rulers previously served in the post of finance minister - also matter, however these results are sensitive to the choice of specification. We also find that leaders who serve in office at a time of economic growth are more likely to turn to private sector employment. This may indicate that the business sector attracts more competent, or perceived as more 
competent, leaders.

Second, while our main focus is on the factors behind post-tenure business careers, we additionally investigate whether leaders with business careers after office presided over different economic policies or outcomes in office. While studies exist in support of leaders' causal effects on economic outcomes (e.g., Besley and Reynal-Querol, 2011a; Jones and Olken, 2005), they typically apply to non-democratic regimes where leaders have more policy discretion. We are skeptical that leaders' effects on economic outcomes can be identified in democracies, however. Still, we examine several economic policies and outcomes in office, and study whether there is any evidence that such policies can be attributed to leaders. If politicians who anticipate business jobs in retirement are less concerned with electoral accountability compared to those who continue their career in politics, they may be more inclined to pursue different economic policies. ${ }^{3}$ Indeed, Besley and Case (1995) and Johnson and Crain (2004) find that the economic policies of "lame-duck" politicians are often different from those who can be re-elected.

We find that even though ex-leaders who seek private employment are indeed associated with specific economic outcomes or policies beyond economic growth — in particular, we examine reduction in state spending but in supplementary materials we turn to several policies that may be perceived as "pro-business" — we do not find evidence, however, to raise concerns over accountability. We find only weak support for the effects of leaders, i.e., that leaders who have more policy discretion and who preside over reductions in spending

${ }^{3}$ First, anticipated career concerns in the business industry may affect behavior while in office (Leaver, 2009). Second, concerns over significantly higher salaries in post-public service roles may influence the type of people seeking public employment in the first place (Caselli and Morelli, 2004; Keane and Merlo, 2010). 
while in office have a higher probability of future private careers. We interpret this finding to support the demand-side explanation of their business careers, i.e., that leaders do not implement policies with future careers in mind; instead it is more likely that the private sector employs former leaders who are perceived to be competent.

The following section discusses factors that make business careers attractive for leaders, as well as those that can make leaders themselves attractive for firms. Next, building on the original data on leaders' careers, we turn to statistical analyses on the determinants of post-office careers. In the subsequent section, we investigate whether policies in office have any sway over future business careers.

\section{The Attraction of the Business Sector to Former Leaders}

The job of head of state or government is arguably the most coveted occupation in any country, representing the pinnacle of a political career. It is unlikely that the majority of former political leaders, given the chance, would not attempt to return to their old office. For example, earlier we referred to the business ventures of the former French leader, Nicolas Sarkozy. Subsequently, his projects were put on hold partly due to the increased difficulties of his successor in office which raised the possibility for Sarkozy to return to politics. It is therefore conceivable that ex-leaders who can still return to high office in the future may remain in politics in another capacity, as leaders of parliamentary parties or governors. In contrast, leaders who are prevented from doing so will be more likely to turn to other careers instead. Furthermore, many cannot run due to various idiosyncratic reasons, e.g., age or health, their own unpopularity or the vagaries of political life.

While we cannot systematically account for various political contingencies that make future returns to politics difficult, we can account for institutions, however. Many leaders 
in parliamentary regimes often serve repeated stints as prime minister and then head parliamentary parties in opposition. In contrast, leaders who are prevented from running for office again, such as presidents due to binding term limits, will be more likely to pursue other careers, be that in the non-profit or for-profit sectors, if they choose not to retire. In general, leaders in parliamentary regimes also have more political experience than presidents (Samuels and Shugart, 2010); therefore the former who invested more in their professional careers as politicians will be less likely to switch to business careers even after losing their premierships.

What are the factors that may attract former leaders to the private sector in retirement from politics? We can draw from the extensive literature on political careers and rewards from political office (e.g., Diermeier, Keane and Merlo, 2005; Eggers and Hainmueller, 2009; Parker, 2008). We know that many democratic politicians postpone their personal wealth acquisition until after leaving political office (e.g., Diermeier, Keane and Merlo, 2005; Eggers and Hainmueller, 2009). This happens because democratic leaders cannot become as wealthy while in office through rent-seeking as their non-democratic peers who have fewer constraints (Baturo, 2014; Bueno de Mesquita et al., 2003). Democratic politicians may also be more public-spirited because of the democratic selection mechanism (Besley and Reynal-Querol, 2011b). It is certainly plausible that the rewards of political office are non-monetary and that leaders seek office for intrinsic reasons or policy. However, it is equally plausible that once politicians, whether public-spirited or not, are out of office, they may be attracted to occupations with higher monetary rewards, especially if they cannot obtain them in the public sector. To account for the attractiveness of the private sector therefore, we can use financial depth, i.e., the relative size of financial institutions in the economy, which also proxies for the availability of high-status private sector jobs. 
The private sector will also be more generally attractive when there is a high salary differential between public and private sectors. In the United States, among the top 350 firms the ratio of the CEO compensation to an average worker increased from 20 to 1 in 1965 to 350 to 1 in 2012, from USD 0.8 million to 12.3 million in estimated earnings. ${ }^{4}$ CEO pay in other democracies is equally high and dwarfs compensation of not only the average worker but also that of the top public servants, including heads of government or cabinet ministers. In a comprehensive survey of CEO pay, the average total compensation for U.S. CEOs was USD 2.5 million and for non-U.S. CEOs USD 1.2 million (Burns, Minnick and Starks, 2013, 11). With the possible exception of Singapore, no political leader is a match to the CEO of a typical corporation in terms of compensation.

While it is difficult to estimate governmental salaries, including those of the heads of state (e.g., Hood, Lee and Peters, 2003), we know that in developed democracies top private sector executives make much more than public executives such as national political leaders, in the order of magnitude of ten, if not higher (Baturo, 2014, 106-8). Using the S\&P ExecuComp data, we estimate that in 2014 the average pay for the CEO of companies with addresses in Canada, the Netherlands, and Switzerland was USD 5.7, 10.1, and 12.4 million respectively. Certainly, while former politicians do not always become CEOs of major companies, they may join company boards instead. Even though financial compensation for board membership does not match that of the CEO, it has also grown over time; politicians may also join multiple boards. ${ }^{5}$ Unfortunately, cross-national data on CEO or

${ }^{4}$ See http://www.epi.org/publication/ceo-pay-2012-extraordinarily-high/, accessed 7 July 2015. We additionally estimate that the total CEO compensation of the Top 100 firms increased from 3.5 to 14.1 million from 1992-2014 (authors' estimates from the S\&P ЕхесиСотр database that is the executive compensation industry standard source).

${ }^{5}$ On average, in 2005 directors made USD 97,000 while in 2014 the figure is 215,000 
board compensation is only available for a handful of countries contemporaneously; there are also methodological difficulties in estimating total compensation across nations. Therefore, to account for the possible attraction of the business sector to former leaders, we rely on U.S. historical data on CEO compensation. While using CEO national pay in the United States to infer business sector attractiveness globally is far from ideal, the market for CEO and board membership talent is global. Indeed, international companies are likely to attract former officials from different countries, not only the US. ${ }^{6}$ Second, CEO compensation in the leading capitalist country is likely to serve as the benchmark for firms across the world concerned with competition for global managerial talent (Fernandes et al., 2012, 348). In fact, non-U.S. companies exposed to international markets have similar CEO compensation as U.S. companies (ibid., 325).

Another factor that may affect whether ex-leaders turn to business in political afterlife is whether such practice is in tune with the norms of behavior accepted in a given society. The business ventures of Sarkozy of France after 2012 may have attracted attention precisely because they did not resonate with the public view on the proper role of former leaders, e.g., different from that of Giscard d'Estaing (1974-81) who remained in party politics after the presidency and then pursued various roles as statesman, such as the President of the Convention on the Future of Europe. One of Sarkozy's supporters had to explain the former president's business interests arguing that "the fact that he is a former president doesn't mean he should become a Trappist monk.."7 In contrast, in other societies, such as the United (authors' estimates from the S\&P ЕxecuComp data).

${ }^{6}$ Ernesto Zedillo (1994-2000) of Mexico joined the boards of Alcoa Inc., Procter \& Gamble, Union-Pacific, and Citigroup. See http://www.bloomberg.com/research/stocks/ people/person. asp?personId=1148781\&ticker=PG, accessed 15 June 2015.

${ }^{7}$ Anne-Sylvaine Chassany and Camilla Hall (2013) "Nicolas Sarkozy's Road from the 
States, the "revolving door" between public office and business may be an established, if not widely accepted, norm. Our expectation therefore is that former politicians in Anglo-Saxon countries - i.e., United States, United Kingdom, Canada, Australia and New Zealand — will be more likely to turn to private employment after politics.

Furthermore, Burns, Minnick and Starks $(2013,20)$ find that cross-national differences in CEO pay can also be explained by cultural norms, such as the perceived desirability of inequality and competition. Negative societal views on the desirability of wealth and private ownership of business may increase reputational costs for former leaders who may contemplate business careers. We therefore additionally investigate whether societies that tolerate inequality, or value wealth acquisition and private business are more likely to have ex-leaders pursuing business careers. Because the data on societal norms are limited, we only employ it in one specification. Instead, we account for economic inequality measured as a Gini coefficient that has more observations. The direction of effects of the Gini coefficient is not entirely clear, however. While economic inequality may account for possible social blowback from taking a high paying private sector job, ${ }^{8}$ at the same time higher inequality may also reflect on the relative attractiveness of lucrative high-paying jobs in society as the income inequality may also be partly explained by increases in the annual compensation of corporate managers (Piketty, 2014, 332). Therefore, while we expect pro-business views and societal tolerance of inequality to increase the likelihood of the business careers of former leaders, we are agnostic regarding the direction of effects of the Gini coefficient however.

While the factors discussed above can make the business sector more attractive to former Elysee to Private Equity", Financial Times, 28 March 2013.

${ }^{8} \mathrm{We}$ are grateful to an anonymous reviewer for pointing it out. 
leaders, we should also consider the demand side — why the private sector may want to hire politicians (Acemoglu et al., 2013). In general, private firms can attract former political leaders because of their superior ability as exemplified by their time in office as heads of state and government that highlights their distinct leadership potential. Such ability can be manifested in the simple fact of their serving in office, or in their background traits - e.g., education - or such ability can be unobservable. There is a growing body of literature that shows political connections, including having former politicians as board members, to be valuable for company value (Faccio, 2006; Fisman, 2001; Hillman, 2005). Therefore, companies may seek former leaders simply because of the prestige of having former heads of states and governments among their corporate board members. In order not to make the argument circular so that all former leaders are attractive to business regardless, we stipulate that leaders who preside over economic growth will be perceived as being more competent and therefore more attractive to the private sector.

As discussed in the introduction, we are not concerned with the identification of leaders' effects on economic outcomes, but rather with those of economic variables on the career trajectories of leaders. Furthermore, while studies exist that identify leaders' effects on the economy in dictatorships (e.g., Besley and Reynal-Querol, 2011a; Jones and Olken, 2005), it is unlikely that leaders' effects can be identified in democracies with many veto players, especially in open economies. Therefore, by including growth as an indicator of competence, we only test for whether market participants perceive that leaders are responsible, not whether they are actually responsible in a causal sense. Because leaders are high-salience individuals, they can be erroneously rewarded or blamed for economic outcomes. ${ }^{9}$

\footnotetext{
${ }^{9}$ Individuals are prone to exaggerate the effects of personal factors and underestimate the role of context. This bias, i.e., the fundamental attribution error, is largely driven by
} 
At the same time such leaders, while perceived as competent, may also be more popular. Indeed, while we lack valid cross-national indicators for governmental popularity, economic growth partly correlates with the popular support for leaders (Bueno de Mesquita et al., 2003, 302-9). In turn, popular leaders may continue in politics as opposed to seeking business employment. In contrast, unpopular leaders may not only be less attractive to highprofile jobs in private sector, they may also be more concerned for their legacy and therefore turn to charitable or non-profit activities to revive their image. ${ }^{10}$

Leaders' own specific traits and experience may also be relevant for what they do after office. The link between leaders' traits of personal background and their political behavior has been shown in the literature (Baturo, 2014; Dreher et al., 2009). It is therefore conceivable that leaders with prior business sector experience will find it easier to return to the private sector after leaving office, similarly to those with economics and business degrees. It is also possible that right-of-center leaders will be more likely to pursue business careers because of their ideological convictions, while left-leaning rulers will be more committed to public service instead. Eggers and Hainmueller $(2009,514)$ who compare the post-office wealth of winning and losing candidates for the UK Parliament, find that holding a seat significantly increases the total personal wealth when former Conservative politicians — but not Labour — are recruited by the private sector. In the US, however, Etzion and errors in perception so that more salient personal factors are more "visible" while context is easier to relegate (Taylor and Fiske, 1975). As a result, competence or lack thereof can be erroneously attributed to leaders under whose watch the economy has improved, whether or not such leaders had any sway over these changes (e.g., Patty and Weber, 2007).

${ }^{10}$ Such as President Carter (1977-81) of the USA who opened the Carter Center instead of seeking private sector employment (Brinkley, 1996). We are grateful for the anonymous reviewer for highlighting this argument. 
Davis (2008, 158-9) find that while the Republican administration attracted more corporate directors than the Democratic, former officials of both parties were equally likely to join corporate boards.

The private sector can attract former political leaders, not only because their political office signals their superior ability but also because of the connections they make in office (Mattozzi and Merlo, 2008). Unfortunately, neither the connections that leaders may acquire with specific firms, nor the identification of services that they render to businesses (e.g., Acemoglu et al., 2013), can be established in a cross-national research design. Certainly, national political leaders make numerous connections while in office. Many of these are unobservable; the data on political donations by private firms over time are lacking for the majority of democratic nations (McMenamin, 2012). Instead, in the empirical section we hypothesize that leaders with longer political experience are able to acquire more political connections, all things being equal. A longer tenure has been shown to be related to better performance and accumulation of specific human capital, with both potentially related to opportunities in the private sector (Brickley, Linck and Coles, 1999). Furthermore, studies also found that markets are sensitive to the quality of public officials with finance portfolios, such as central bankers for instance (Gohlmann and Vaubel, 2007). Therefore, we additionally account for whether former political leaders previously served as finance ministers or treasury secretaries — the posts that may have permitted leaders to acquire business connections.

In summary, leaders can be attracted to business careers because they are prevented from pursuing the highest political office by institutional constraints, or because of their own personal traits, but also if private careers are especially financially rewarding. In turn, leaders can also be attractive to business because of the mere prestige of having such high-profile 
individuals on the board, or due to their connections, or their perceived competence. ${ }^{11}$

\section{Business Careers of Former Leaders: the Data}

We examine whether former national political leaders turn to business careers after leaving office, as opposed to staying in politics or pursuing other occupations, such as careers in international organizations or non-profit foundations, for example. The binary dependent variable, therefore, is whether upon leaving office leaders move into the business sector versus other careers. In the period 1960-2010 almost 800 leaders exit office in democracies, i.e., with Polity $2 \geq+6$. We exclude leaders that go into exile, experience immunity problems that lead to prosecution, or die shortly after leaving office — in other words, we only

${ }^{11}$ Additionally, the private sector may also recruit leaders as a reward (Mattozzi and Merlo, 2008). Eggers and Hainmueller $(2009,531)$ argue that politicians who help firms while in office, accrue wealth via "lucrative employment opportunities provided to politicians after retirement." Tenure in office of national leaders, however, coincides with all kinds of economic, financial, and social policies implemented at the time; it is not necessarily correct to attribute causality between policies implemented by leaders' governments in certain sectors of the economy and their employment by firms in those sectors. Furthermore, exleaders typically work for several companies and run their own business consulting interests in retirement (e.g., Schweizer, 2015). The identification of post-tenure careers as possible rewards is extremely difficult even at the lower levels of government or specific branches thereof. For instance, the movement of former military generals into the boards of military contractors may simply indicate that the former have the required experience gained from the public job (Etzion and Davis, 2008). Therefore, we do not pursue the reward hypothesis in a cross-national setting. Still, in further and supplementary analyses we briefly examine whether economic performance and "pro-business" policies in office are associated with future business careers and whether leaders can be shown to influence such policies. 
focus on leaders who in principle can have further careers after leaving office. ${ }^{12}$ Discarding the most immediate period after leaving office when leaders almost always take some time off, altogether there are 551 former leaders who exit office and have future careers. We find that there are 75 former rulers, or 14 percent in all, who pursue some kind of business career after leaving office, and 476 pursue other types of careers.

What constitutes the business career of political leaders after leaving office? We record leaders as having a predominantly business career when their future careers include membership of corporate boards, consulting for private companies, law practice, or running their own business For example, Jan de Quay (1959-63) of the Netherlands was the chairman of Royal Dutch Airlines (Lentz, 1994, 579), Geoffrey Palmer (1989-90) of New Zealand ran his own private law practice, and Natsagiin Bagabandi of Mongolia (1997-2005) joined the board of a mining company. Some leaders may be involved in more than one type of career upon retirement. For example, Tony Blair, in addition to his predominantly business career that brought him "millions of pounds from a mix of business interests that include advising governments, consultancy work for US investment bank JP Morgan and the lucrative international speaking circuit, ${ }^{13}$ also headed a charitable foundation. While the predominant majority of leaders can be classified in one category, it is unavoidable that some must be entered in more than one, as this represents a fact of their careers and not a failure of categorization. Indeed, to choose one category over another would be arbitrary when a former

${ }^{12}$ Fully retired leaders are also excluded. Retirement is defined as when a leader retires from public life altogether and there is no record of such leader pursuing any kind of career in retirement. It is conceivable that some leaders are mis-categorized because of the lack of available data. In the supplementary analyses we conduct sensitivity tests.

13"Tony Blair businesses amass $£ 13 \mathrm{~m}$ cash after surge in profits," Guardian, 5 January 2014, Katie Allen. 
leader is reported to be engaged in more than one activity. In the supplementary analyses we examine alternative specifications, however.

\section{[FIGURE 1 ABOUT HERE]}

The percentage of former leaders in business is relatively stable over the period 19602010 with the average being 14 percent, and 17 percent in the period in the 2000s. This suggests that the so-called "Blair Disease" is not a recent phenomenon and such moves to the private sector have not become more prevalent over time. If there is any pattern, it is a slight increase in the percentage of former leaders in business compared to those who remain in politics, as opposed to all types of post-office pursuits. However, we compare business careers with all future careers, be that remaining in politics as party leader or working for international organizations, and therefore we are not concerned with an underlying time trend.

To account for the possible attractiveness of business careers to leaders in society, we include Financial depth, Income per capita, logarithm, average CEO compensation, Inequality measured as Gini index of household disposable (post-tax, post-transfer) income - all for the last year in office. Parliamentary regime is included to control for the possibility of political careers in the future. Term limits are strongly collinear with parliamentarianism as almost all democratic presidents face binding tenure limitation, and are therefore excluded. Additionally, we include Right ideology and a prior Business career of leaders, coded from biographical entries. Likewise, we account for age at the time of departure from office as older leaders may have less stamina to withstand the stress of yet another high-status job. All leader-related indicators are time-invariant (Baturo, 2014). In a separate specification we include the World Values Survey's (WVS) Income equality, Business ownership and Wealth accumulation to account for cultural norms. Higher values stand for "We need larger income 
differences as incentives for individual effort", "Private ownership of business and industry should be increased" and "Wealth can grow so there's enough for everyone", respectively. We also use additional indicators of individual background and pro-business policies in office as detailed in the supplementary materials.

\section{What Explains the Business Careers of Former Leaders?}

We estimate a probit model where we specify the probability of a leader joining private sector upon exit from office as a function of indicators for various country and personal traits. Our dependent variable in all estimations is a binary indicator denoting leaders who go into business after leaving office versus any other active occupational pursuit they may undertake (political, academic or public service). In our estimations, the unit of analysis is a political leader retiring from political office during the time period 1960-2010. As explained above, the independent variables are either averaged per tenure or take the values for the last year in office. Since leaders from the same country are not independent observations, all our estimations are done with robust standard errors clustered by country.

In our analysis we estimate three main specifications: in the first, our baseline model, we aim to account for private sector attraction and country characteristics in leaders' decision to move to the private sector (Model 1 in Table 1). The second specification focuses on specific leader traits that may make them desirable to the private sector (Model 2 in Table 1). We also explore a combination of the first two specifications (Model 3-4 in Table 1). Yet another specification extends the first two by further examining societal norms like inequality and wealth desirability (Model 5 in Table 1).

Our baseline model (Model 1 in Table 1) specifies the probability of moving to private sector as a function of country's level of economic development (Income per capita), 
whether the country is a parliamentary democracy, whether it belongs to countries with an Anglo-Saxon tradition, the level of economic inequality, its financial depth, and the benchmark CEO compensation in the private sector.

In turn, Model 2 in Table 1 accounts for the business and economic education background of leaders. Indeed, leaders with specific background traits may be more attractive to business. Also, to account for the magnitude of political connections made in office we additionally include Years in politics - only years in official politics prior to assuming the highest office are counted, such as being a member of parliament, cabinet minister, governor, and the like. Likewise, Ex finance minister is included as an additional measure of the attractiveness of leaders to the business sector. Finally, we hypothesize that higher economic growth, measured over the leader's tenure, may render leaders more attractive or signal their competence to firms.

We explore a combination of our first two specifications in Models 3-4 that combine two explanations for leaders' future careers. Models 3 and 4 differ in that the latter is fitted controlling for time invariant country specific characteristics using a conditional logit. When the outcomes do not vary within a country, the fixed effects estimation loses observations for countries where either all or no leaders went into the private sector, in addition to any other time invariant variables like Parliamentary democracy and Anglo-Saxon countries.

In Model 5 we explore whether the propensity to take high-paying private sector jobs is associated with societies with a higher tolerance for inequality and those that value business pursuits. We replace our measure of inequality from the combined model (Model 3) with the WVS indicators for prevailing cultural attitudes, Income equality, Business ownership and Wealth accumulation. Anglo-Saxon indicator is excluded since it is associated with the cultural attitudes of such countries. 
The results of the first model specification in Table 1 indicate that former leaders in Anglo-Saxon countries are more likely to pursue business careers in retirement. Likewise, while the indicator for average annual CEO compensation in the American economy is only a benchmark for the likely compensation in the global market, its coefficient is also statistically significant. Inequality and Financial depth both also have the expected direction of effects but the coefficients are not statistically significant.

The results of Model 2 suggest that neither economic education of leaders, nor the length of their political careers can predict their future business careers. The selected measures are admittedly rather crude as a longer time in politics can also indicate that the individual is a career politician and therefore has not only developed more political connections but is also more likely to remain in politics. It is also somewhat collinear with Age and therefore the negative sign of its coefficient can simply mean that more experienced politicians are also older. We interpret the results in Model 2 to indicate that relevant business connections developed by former politicians while in office are difficult to observe. However, leaders who pursued business careers before becoming politicians are more likely to return to the private sector after leaving office, as evidenced by the statistically significant coefficient on Business career in all model specifications. Likewise, leaders who preside over a growing economy are more likely to turn to the private sector in retirement. A former Finance minister is also more likely to turn to business, albeit the coefficient is statistically significant at the level of 0.1 only.

Estimation results of combined specification (Models 3-4) broadly support those from earlier specifications: leaders' personal background, as well as growth in disposable income over tenure matter for their private sector careers. Likewise, Model 3 reveals that CEO com- 
pensation and Anglo-Saxon capitalist model are positively associated with the propensity to take up jobs in the private sector, the former albeit at the 0.1 level. The fixed effects estimation results in Model 4 are also in line with previous estimates. Using "full" Model 3 and holding other predictors at their means, we can additionally assess the predictive margins. We find that when leaders with prior business experience preside over high economic growth at 2 standard deviations above the sample average, there is 47 percent probability of a future business career as opposed to 17 percent probability of such leaders with the growth at 2 standard deviations below the average.

The results in Model 5 in Table 1 show that all three World Values Survey predictors have the expected sign of the coefficient but only Business ownership is statistically significant. The result suggests that a stronger sentiment for "Private ownership of business and industry should be increased" is indeed associated with the business careers of leaders. Unfortunately, we cannot include "pro-business" survey indicators in the fixed effects model specification as it reduces the sample size by more than two thirds.

In summary, former Anglo-Saxon leaders and those with prior business careers are more likely to turn to private sector employment in retirement, especially when CEO pay rates are high. Individual background matters: one in every three leaders who pursued business careers after leaving office already had such a career before. In contrast, only one in ten without prior business credentials made such a switch. Still, the majority of leaders who pursued a business career after office had no prior business background. There is also evidence that leaders who occupied finance ministry in the past, as well as leaders in societies that favor private sector pursuits, will be attracted to business careers after office. We find no evidence that ideology plays any role in the likelihood of leaders' future business careers. 


\section{Further Analyses: Performance in Office and Business Careers}

Are former leaders who turn to business careers in retirement associated with different economic outcomes and policies beyond economic growth? While our primary aim was to find what individual and structural factors are associated with "revolving door" phenomenon among ex-leaders - investigated in the section above - we can also examine whether former leaders who had presided over specific economic policies or outcomes in office are more likely to turn to private employment than those who turn to other careers or continue in politics. In this section, therefore, we discuss what policies may be attractive to business and whether leaders can in fact be responsible for such policies.

Previously we showed that growth over tenure is strongly associated with the future business careers of leaders. Outside actors may also form an opinion about a leader from comparing economic performance of a country in relation to the wider world economy. Model 1 in Table 2 which is a simplified version of the "full" model in Table 1, i.e., excludes several indicators for individual traits, includes an indicator that compares national growth rates over average world growth rate to capture whether an individual country is under- or over-performing compared to other countries, and also to control for wider global economic slowdowns that voters or firms are unlikely to hold against a leader. As can be seen in Table 2, the new indicator is a statistically significant predictor of the likelihood of business careers.

Generally, incumbent politicians are more likely to be re-elected if they preside over income growth or other desirable outcomes such as reduction in unemployment (for review see Mueller, 2003, 429-71). In principle, office-seeking politicians have incentives to implement policies that benefit their constituents. Because the modern welfare state has a very 
large constituency, cutting various spending programs is generally unpopular with the electorate (Pierson and Smith, 1993). At the same time, reducing the overall size of government is an often-propagated goal of business-friendly politicians manifesting economically liberal policy preferences and it may endear them to the business community even if it is only due to ideological convergence on this issue.

In practice, the retrospective accountability for economic outcomes can be contaminated by various factors; politicians who roll back spending can employ various blame avoidance strategies (e.g., Vis and van Kersbergen, 2007). Still, following the recent Eurozone economic crisis, several governments that turned to the harshest austerity measures — such as those of Portugal, Greece, Ireland and Spain — were all voted out of office during 2011. Out of office they may be, but former political leaders have other career options. For instance, Brian Cowen (2008-11) of Ireland, who presided over "the most austere Budget in the history of the State", in retirement set up a consultancy and joined the energy company board. ${ }^{14}$ While reasons behind the choice of austerity abound, from creditor pressure to government ideology, the possibility of private sector careers may ease the political costs of unpopular policies for incumbent leaders. If leaders can foresee lucrative employment opportunities should they not be re-elected, they may be more likely to reduce spending or cut programs than otherwise, and will therefore be less concerned with electoral accountability.

Fiscal policy is a key government tool affecting the wider economy and specifically private sector performance (e.g. Blanchard and Perotti, 2002). We follow the standard approach in the field and assess fiscal policy performance in terms of public spending as it

${ }^{14}$ The quote is from Harry McGee, "Few Surprises in Much-leaked Budget, " The Irish Times, 9 December 2009. On employment, see Conor Ryan, "Cowen Appointed to Board of O'Brien's Topaz Energy", Irish Examiner, 3 May 2014. 
has the widest cross-section and time-series data coverage. Model 2 in Table 2 includes Spending change, levels, measured as a change in the total level of governmental spending over a leader's tenure. Government spending, however, is likely to depend on economic cycles, with automatic stabilizers potentially obfuscating the degree of governmental control over spending. At the same time, firms will be likely to form an opinion of leaders' performance from their assessment of discretionary decisions over fiscal policy. ${ }^{15}$ In order to address this issue we create a measure of discretionary spending - explained in detail in the appendix — that captures discretionary policy that is driven by reasons unrelated to current macroeconomic conditions (Fatás and Mihov, 2003). This alternative measure of government spending is included in Model 3.

In line with expectations, the results of Models 2-3 suggest that leaders presiding over reductions in spending have a higher probability of moving to the private sector. Do these results imply that there exist valid concerns for democratic accountability however? First, leaders who experience significant state contraction may simply be no longer attractive to the electorate and so they make a rational career change, turning to business careers instead. If this is the case, the expectation of future careers does not influence their policy-making while in office. However, another and more problematic possibility is seen in the results of Models 2-3 which imply that if a leader counts on a business career in the future, he or she may be less reluctant to enact unpopular policies.

Is it possible to identify whether political leaders are in fact responsible for changes in economic performance and policy implementation? Scholars of leadership who seek to prove that leaders are able to translate their preferences into policies and that the latter, not other actors, institutions, or larger structural factors, are the "causes" behind specific eco-

\footnotetext{
${ }^{15}$ We thank an anonymous reviewer for this suggestion.
} 
nomic outcomes find it close to impossible to do so in a non-experimental setting (Ahlquist and Levi, 2011). We accept that complex economic outcomes, such as changes in spending or economic growth are driven by a battery of factors in the domestic and international political economy, institutions and actor configurations; governments enact a plethora of policies in different domains of the economy, and regulate and deregulate specific industries. Country leaders are not free to exert policy influence. Instead, they are often constrained by constitutions as well as other veto players, like legislatures or coalition partners (Tsebelis, 2002).

Because accountability is generally diminished by institutions (e.g., Alesina and Rosenthal, 1995), as a simple test as to whether leaders can conceivably be seen as responsible for economic changes that occur while they are in office, we interact existing policy constraints (Henisz, 2002), averaged over each leader's tenure, with changes in spending and economic growth. If leaders are indeed somewhat responsible rather than serendipitously governing while the economy is driven by other factors and actors, then we expect that less constrained rulers who experience a reduction in spending and higher growth, would be in higher demand by the private sector. Table 2 therefore contains Models 4 and 5 that include simple interaction terms between constraints and two economic indicators each, while Model 6 presents a full interactive model (e.g., Braumoeller, 2004).

\section{[TABLE 2 ABOUT HERE]}

\section{[FIGURE 2 ABOUT HERE]}

There is, however, no interrelationship between observable economic indicators of performance in office and political constraints: none of the interactive terms are statistically significant (Models 4-6). For robustness we further interact the same economic performance indicators with three more measures of constraints, averaged per tenure. We use measures of 
governmental control of legislature (a dummy variable All house), Polarization between the executive party and those of the legislature, and Fractionalization, the probability of picking two pro-governmental legislators from different parties (Beck et al., 2001). Higher values of Polarization and Fractionalization indicate stronger executive constraints. The estimation results with these alternative measures of constraints are presented in supplementary materials. Here we only show marginal plots of predicted probabilities from the analysis in Figure 2. The rows in Figure 2 display the predicted probability of a private sector career when Spending $\triangle$ is reduced at two standard deviations below the mean, while Growth is at two standard deviations above it, over the range of four indicators of constraints.

The flat lines in Figure 2 suggest that less and more constrained leaders alike have equal chances of business careers. The difference in the probabilities of landing a private sector job between more and less constrained leaders who have equally presided over spending reductions in office is only in single percentage points and not statistically significant. While this represents only a very indirect test of the identification of leaders' effects, all four selected indicators of constraints point in the direction of either weak or no effect. We interpret these findings to indicate that leaders who foresee a business career in the future do not implement specific policies with such careers in mind. Instead, it is more probable that it is the private sector that attracts leaders who merely appear responsible for economic outcomes.

In the supplementary materials we examine whether various policy changes that can be interpreted as pro-business, for example, changes in Economic freedom index, trade openness, investment attractiveness or other policies, have sway over future leaders' careers. Adoption and implementation of pro-business policies can send a clear signal to the private sector about the individual's type. In turn, this makes such politicians into viable candidates for executive positions in the private sector if they decide to explore such opportunities upon 
leaving office. The results are broadly in line with those reported in the paper: while leaders who experience "pro-business" policies in office are indeed more likely to turn to business careers in the future, we can only conclude that they are perceived as responsible, despite not in fact being responsible in the causal sense. The supplementary materials also provide various sensitivity analyses including different specifications of the dependent variable, different estimation sample, and different operationalization of predictors, among other things. Likewise, we include interactions with the discretionary spending measure. We find that the supplementary analyses support the main results reported above.

\section{Conclusions}

The public attention that Tony Blair attracted, alongside that of his peers who also opted to pursue wealth after leaving office, led many observers to conclude that the pursuit of business careers by prominent politicians is a very recent phenomenon. ${ }^{16}$ Clearly, it is not. Many leaders in the period 1960-2010 abandoned their prior political career for one in the private sector, or returned to a previously-held business career. Our main aim was to investigate the determinants of the future business careers of political leaders. We found that global CEO compensation rates, whether leaders had served in Anglo-Saxon nations, cultural norms, as well as their prior business careers, contribute to the explanation. We also found that economic growth and reduction in state spending were related to the future private sector careers of leaders. If politicians who oversee reductions in public expenditure turn

\footnotetext{
16“No previous European ex-leaders made this kind of dough. Just 20 years ago the British ex-prime minister Harold Wilson was showing up at the House of Lords stricken with Alzheimer's, led by his nurse, because he needed the daily attendance fee". Kuper, op. cit.
} 
to business occupations in retirement, it may suggest another possible causal mechanism as to why electoral accountability does not always work. Indeed, political leaders may discard the political costs of austerity or other unpopular policies not only because of their ideological convictions but also if they foresee alternative careers after office. The report in Financial Times from which we borrowed the title of this paper argued that "consciously or not, farsighted leaders behave like future employees of the rich" (Kuper, op. cit.). We are reluctant, however, to argue that leaders implement policies with future careers in mind. While it cannot be adequately tested in a cross-national study, it is also extremely unlikely at the top level of political leadership, and a simple test that we conducted in the second empirical section supports this conclusion.

We hope that the paper brings new perspective on the politics of "revolving doors", providing analyses of the determinants of public and private sector career changes at the highest echelons of leadership for the first time. Likewise, it offers new data on the prior and future business careers of democratic leaders, as well as rigorous analyses that account for the economy, societal norms, institutions, and leaders' perceived performance in office. Future studies can establish if sector-specific policies enacted in office are associated with the firms for which political leaders work in retirement. Likewise, further qualitative studies can also shed more light on whether leaders who have "pro-business" economic preferences and are responsible for policy implementation that favors business, are indeed more likely to go through the "revolving doors" in retirement. 


\section{References}

Acemoglu, Daron, Simon Johnson, Amir Kermani, James Kwak and Todd Mitton. 2013. "The Value of Connections in Turbulent Times: Evidence from the United States." National Bureau of Economic Research Working paper 19701.

Ahlquist, John and Margaret Levi. 2011. "Leadership: What It Means, What It Does, and What We Want to Know About It.” Annual Review of Political Science 14:1-24.

Alesina, Alberto and Howard Rosenthal. 1995. Partisan Politics, Divided Government and the Economy. Cambridge: Cambridge University Press.

Baturo, Alexander. 2014. Democracy, Dictatorship, and Term Limits. Ann Arbor, MI: Michigan University Press.

Beck, Thorsten, George Clarke, Alberto Groff, Philip Keefer and Patrick Walsh. 2001. "New Tools in Comparative Political Economy: The Database of Political Institutions." World Bank Economic Review 15:165-176.

Bertrand, Marianne, Matilde Bombardini and Francesco Trebbi. 2014. "Is It Whom You Know or What You Know? An Empirical Assessment of the Lobbying Process." American Economic Review 104(12):3885-3920.

Besley, Timothy and Anne Case. 1995. "Does Electoral Accountability Affect Economic Policy Choices? Evidence from Gubernatorial Term Limits." The Quarterly Journal of Economics 110(3):769-98.

Besley, Timothy, Jose Montalvo and Marta Reynal-Querol. 2011a. "Do Educated Leaders Matter?" Economic Journal 121(205-227).

Besley, Timothy and Martha Reynal-Querol. 2011b. "Do Democracies Select More Educated Leaders?" American Political Science Review 105(3):552-66.

Blanchard, Olivier and Roberto Perotti. 2002. "An Empirical Characterization of the Dynamic Effects of Changes in Government Spending and Taxes on Output." Quarterly Journal of Economics 117(4):1329-1368.

Blanes i Vidal, Jordi, Mirko Draca and Christian Fons-Rosen. 2012. "Revolving Door Lobbyists." American Economic Review 102(7):3731-48. 
Braumoeller, Bear. 2004. "Hypothesis Testing and Multiplicative Interaction Terms." International Organization 58:807-820.

Brickley, James, James Linck and Jeffrey Coles. 1999. "What Happens to CEOs after They Retire? New Evidence on Career Concerns, Horizon Problems, and CEO Incentives." Journal of Financial Economics 52(3):341-377.

Brinkley, Douglas. 1996. "The Rising Stock of Jimmy Carter: The "Hands on" Legacy of Our Thirty-ninth President." Diplomatic History 20(4):505-30.

Bueno de Mesquita, Bruce, Alastair Smith, Randolph Siverson and James Morrow. 2003. The Logic of Political Survival. Cambridge, Mass.: MIT Press.

Burns, Natasha, Kristina Minnick and Laura Starks. 2013. "CEO Tournaments: A CrossCountry Analysis of Causes, Cultural Influences and Consequences.” Mimeo. Available at SSRN: http://ssrn.com/abstract=2010095.

Caselli, Francesco and Massimo Morelli. 2004. "Bad Politicians." Journal of Public Economics 88(3-4):759-82.

Cohen, Jeffrey. 1986. "The Dynamics of the "Revolving Door" on the FCC." American Journal of Political Science 30(4):689-708.

Diermeier, Daniel, Michael Keane and Antonio Merlo. 2005. "A Political Economy Model of Congressional Careers." American Economic Review 95(1):347-373.

Dreher, Axel, Sarah Lein, Michael Lamla and Frank Somogyi. 2009. "The Impact of Politicans' Profession and Education on Reforms." Journal of Comparative Economics 37(1):169-93.

Eggers, Andrew and Jens Hainmueller. 2009. "MPs for Sale? Returns to Office in Postwar British Politics." American Political Science Review 103(4):513-33.

Etzion, Dror and Gerald Davis. 2008. "Revolving Doors? A Network Analysis of Corporate Officers and US Government Officials.” Journal of Management Inquiry 17(3):157-61.

Faccio, Mara. 2006. "Politically Connected Firms." The American Economic Review 96(1):369-386. 
Fatás, Antonio and Ilian Mihov. 2003. "The Case for Restricting Discretionary Fiscal Policy." Quarterly Journal of Economics 118(4):1419-1447.

Fernandes, Nuno, Miguel Ferreira, Pedro Matos and Kevin Murphy. 2012. "Are U.S. CEOs Paid More? New International Evidence.” Review of Financial Studies 26(2):323-67.

Fisman, Raymond. 2001. "Estimating the Value of Political Connections." American Economic Review 91(4):1095-1102.

Goemans, Hein. 2008. "Which Way Out? The Manner and Consequences of Losing Office." Journal of Conflict Resolution 53(6):771-794.

Gohlmann, Silja and Roland Vaubel. 2007. "The Educational and Professional Background of Central Bankers and its Effect on Inflation - An Empirical Analysis." European Economic Review 51(4):925-942.

Henisz, Witold. 2002. “The Institutional Environment for Infrastructure Investment.” Industrial and Corporate Change 11(2):334-363.

Hillman, Amy. 2005. "Politicians on the Board of Directors: Do Connections Affect the Bottom Line?" Journal of Management 31(3):464-481.

Hood, Christopher, Grace Lee and Guy Peters. 2003. Reward for High Public Office: Asian and Pacific Rim States. London: Routledge.

Johnson, Joseph and Mark Crain. 2004. "Effects of Term Limits on Fiscal Performance: Evidence from Democratic Nations.” Public Choice 119(1/2):73-90.

Jones, Benjamin and Benjamin Olken. 2005. "Do Leaders Matter? National Leadership and Growth Since World War II." Quarterly Journal of Economics 120(3):835-864.

Keane, Michael and Antonio Merlo. 2010. "Money, Political Ambition, and the Career Decisions of Politicians.” American Economic Journal: Microeconomics 2(3):186-215.

Leaver, Clare. 2009. "Bureaucratic Minimal Squawk Behavior: Theory and Evidence from Regulatory Agencies.” The American Economic Review 99(3):572-607.

Lentz, Harris. 1994. Heads of States and Governments: a Worldwide Encyclopedia of Over 2,300 Leaders, 1945 through 1992. London: McFarland and Co. 
Mattozzi, Andrea and Antonio Merlo. 2008. "Political Careers or Career Politicians?" Journal of Public Economics 92(3):597-608.

McMenamin, Iain. 2012. "If Money Talks, What Does It Say? Varieties of Capitalism and Business Financing of Parties.” World Politics 64(1):1-38.

Mueller, Dennis. 2003. Public Choice III. Cambridge: Cambridge University Press.

Parker, Glenn. 2008. Capitol Investments: The Marketability of Political Skills. Ann Arbor, MI: University of Michigan Press.

Patty, John and Roberto Weber. 2007. "Letting the Good Times Roll: A Theory of Voter Inference and Experimental Evidence." Public Choice 130:293-310.

Pierson, Paul and Miriam Smith. 1993. "Bourgeois Revolutions? The Policy Consequences of Resurgent Conservatism.” Comparative Political Studies 25(4):487-520.

Piketty, Thomas. 2014. Capital In the Twenty-First Century. Cambridge: Cambridge University Press.

Samuels, David and Matthew Shugart. 2010. Presidents, Parties, and Prime Ministers: How the Separation of Powers Affects Party Organization and Behavior. Cambridge: New York: Cambridge University Press.

Schweizer, Peter. 2015. Clinton Cash: The Untold Story of How and Why Foreign Governments and Businesses Helped Make Bill and Hillary Rich. New York: Harper.

Taylor, Shelley and Susan Fiske. 1975. "Point of View and Perceptions of Causality." Journal of Personality and Social Psychology 32(3):439-445.

Tsebelis, George. 2002. Veto Players: How Political Institutions Work. Princeton, NJ: Princeton University Press.

Vaubel, Roland, Bernhard Klingen and David Muller. 2011. "There Is Life after the Commission: An Empirical Analysis of Private Interest Representation by Former EUCommissioners, 1981-2009." The Review of International Organizations 7(1):59-80.

Vis, Barbara and Kees van Kersbergen. 2007. "Why and How do Political Actors Pursue Risky Reforms?” Journal of Theoretical Politics 19(2):153-172. 


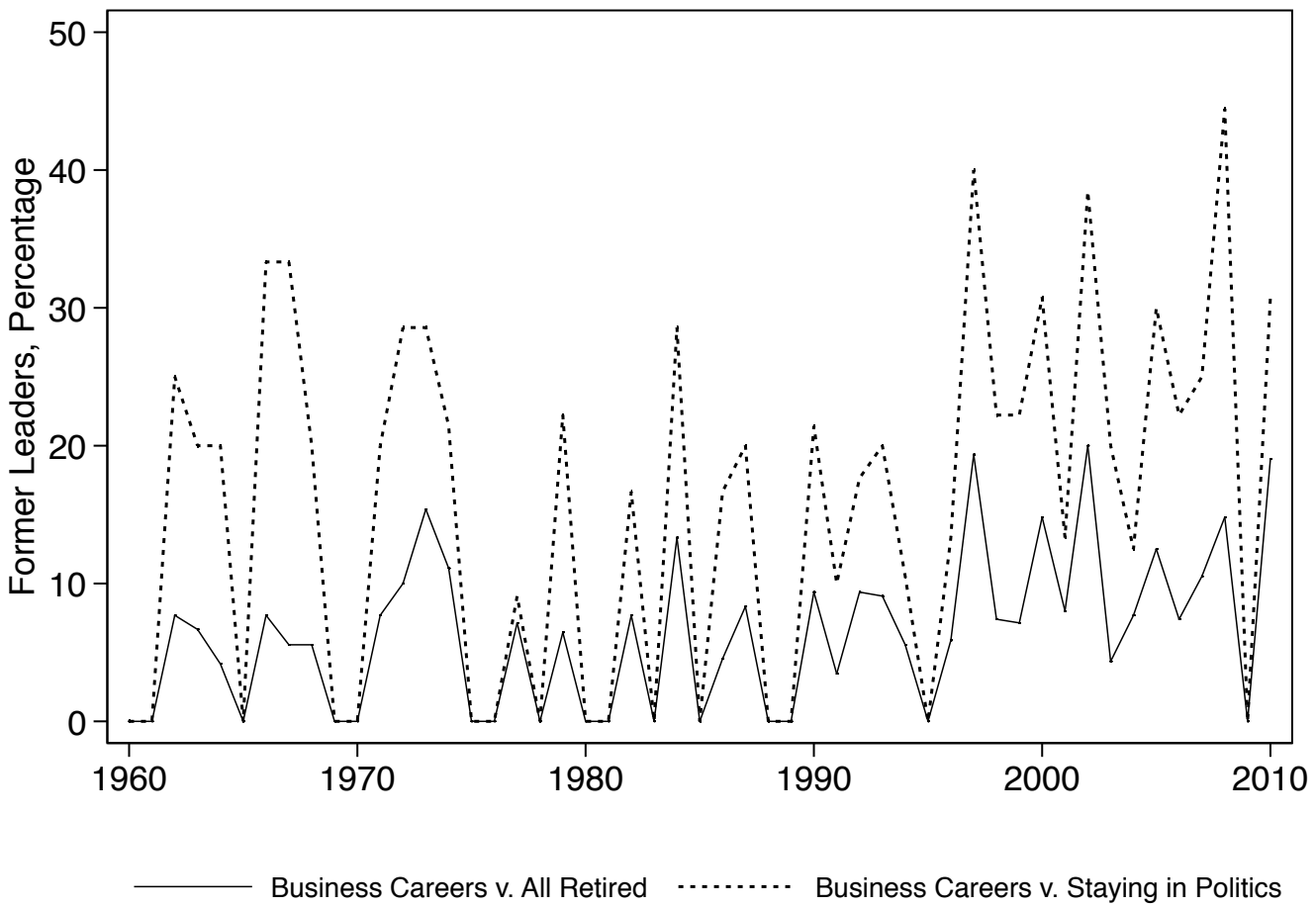

Figure 1: Former Leaders in Business Careers, 1960-2010. 


\begin{tabular}{|c|c|c|c|c|c|}
\hline & \multirow{2}{*}{$\begin{array}{c}\text { economy } \\
1:\end{array}$} & \multirow{2}{*}{$\begin{array}{c}\text { traits } \\
2 \text { : }\end{array}$} & \multicolumn{2}{|c|}{ full } & \multirow{2}{*}{$\begin{array}{c}\text { soc. norms } \\
5:\end{array}$} \\
\hline & & & 3: & 4: & \\
\hline Income pc (log) & $\begin{array}{c}0.040 \\
(0.306)\end{array}$ & $\begin{array}{c}0.286 \\
(0.201)\end{array}$ & $\begin{array}{c}0.041 \\
(0.296)\end{array}$ & $\begin{array}{c}0.246 \\
(3.907)\end{array}$ & $\begin{array}{l}-0.080 \\
(0.396)\end{array}$ \\
\hline Financial depth & $\begin{array}{c}0.002 \\
(0.002)\end{array}$ & - & $\begin{array}{c}0.001 \\
(0.002)\end{array}$ & $\begin{array}{l}-0.003 \\
(0.011)\end{array}$ & $\begin{array}{c}0.005 \\
(0.004)\end{array}$ \\
\hline Inequality & $\begin{array}{c}0.010 \\
(0.013)\end{array}$ & - & $\begin{array}{c}0.005 \\
(0.013)\end{array}$ & $\begin{array}{c}0.124 \\
(0.079)\end{array}$ & - \\
\hline Parliamentary dem. & $\begin{array}{c}0.253 \\
(0.249)\end{array}$ & $\begin{array}{c}0.061 \\
(0.195)\end{array}$ & $\begin{array}{c}0.235 \\
(0.248)\end{array}$ & - & $\begin{array}{c}0.544 \\
(0.346)\end{array}$ \\
\hline Anglo-Saxon countries & $\begin{array}{c}1.109 * * * \\
(0.181)\end{array}$ & $\begin{array}{c}0.888 * * * \\
(0.194)\end{array}$ & $\begin{array}{c}1.131 * * * \\
(0.218)\end{array}$ & - & - \\
\hline CEO compensation & $\begin{array}{c}0.049 * * \\
(0.018)\end{array}$ & - & $\begin{array}{l}0.033+ \\
(0.018)\end{array}$ & $\begin{array}{c}0.051 \\
(0.064)\end{array}$ & $\begin{array}{c}0.014 \\
(0.029)\end{array}$ \\
\hline Right ideology & - & $\begin{array}{c}0.101 \\
(0.173)\end{array}$ & $\begin{array}{c}0.025 \\
(0.200)\end{array}$ & $\begin{array}{l}-0.505 \\
(0.437)\end{array}$ & $\begin{array}{l}-0.163 \\
(0.240)\end{array}$ \\
\hline Years in politics & - & $\begin{array}{l}-0.008 \\
(0.007)\end{array}$ & $\begin{array}{l}-0.005 \\
(0.009)\end{array}$ & $\begin{array}{l}-0.009 \\
(0.022)\end{array}$ & $\begin{array}{c}-0.025 * * \\
(0.010)\end{array}$ \\
\hline Business career & - & $\begin{array}{c}0.890 * * * \\
(0.228)\end{array}$ & $\begin{array}{c}0.893 * * * \\
(0.254)\end{array}$ & $\begin{array}{l}1.321 * * \\
(0.518)\end{array}$ & $\begin{array}{l}0.618+ \\
(0.346)\end{array}$ \\
\hline Ex finance minister & - & $\begin{array}{l}0.398+ \\
(0.214)\end{array}$ & $\begin{array}{c}0.299 \\
(0.296)\end{array}$ & $\begin{array}{c}0.154 \\
(0.673)\end{array}$ & $\begin{array}{c}0.064 \\
(0.359)\end{array}$ \\
\hline Economics degree & - & $\begin{array}{l}-0.208 \\
(0.184)\end{array}$ & $\begin{array}{l}-0.125 \\
(0.221)\end{array}$ & $\begin{array}{c}0.059 \\
(0.511)\end{array}$ & $\begin{array}{l}-0.253 \\
(0.266)\end{array}$ \\
\hline Leader's age & - & $\begin{array}{c}-0.016+ \\
(0.008)\end{array}$ & $\begin{array}{c}-0.015+ \\
(0.009)\end{array}$ & $\begin{array}{l}-0.024 \\
(0.026)\end{array}$ & $\begin{array}{l}-0.002 \\
(0.014)\end{array}$ \\
\hline Growth over tenure & - & $\begin{array}{c}0.010 * * \\
(0.005)\end{array}$ & $\begin{array}{c}0.015 * * \\
(0.006)\end{array}$ & $\begin{array}{c}0.036 * * \\
(0.016)\end{array}$ & $\begin{array}{c}0.027 * * \\
(0.010)\end{array}$ \\
\hline Income equality, WVS & - & - & - & - & $\begin{array}{c}0.039 \\
(0.151)\end{array}$ \\
\hline Private business, WVS & - & - & - & - & $\begin{array}{c}0.344 * * \\
(0.169)\end{array}$ \\
\hline Wealth accumulation, WVS & - & - & - & - & $\begin{array}{c}0.158 \\
(0.232)\end{array}$ \\
\hline Constant & $\begin{array}{c}-2.363+ \\
(1.326)\end{array}$ & $\begin{array}{c}-1.660 * * \\
(0.845)\end{array}$ & $\begin{array}{l}-1.516 \\
(1.347)\end{array}$ & - & $\begin{array}{c}-4.647+ \\
(2.529)\end{array}$ \\
\hline $\mathrm{N}$ & 436 & 536 & 431 & 228 & 239 \\
\hline $\mathrm{N}$ countries & 87 & 93 & 86 & 32 & 52 \\
\hline Log-likelihood & -155.660 & -185.771 & -141.657 & -69.836 & -79.076 \\
\hline
\end{tabular}

Table 1: Business Careers of Former Democratic Leaders Note: All estimations exclude leaders who retired, went into exile, were arrested or jailed after leaving office. The choice of occupation is compared with other "active pursuits", e.g., international or non-profit careers. Models 1-3 and 5 are probit regression models with standard errors clustered by country, Model 4 is conditional logit (fixed effects) estimation. The number of observations differs as fixed effects estimation drops countries with time-invariant variables, e.g., Parliamentary dem.. Models 1, 3-4 are via multiple imputation. $+\mathrm{p}<0.10, * * \mathrm{p}<0.05, * * * \mathrm{p}<0.01$. 


\begin{tabular}{|c|c|c|c|c|c|c|}
\hline & \multicolumn{3}{|c|}{ spending } & \multicolumn{3}{|c|}{ constraints } \\
\hline & 1: & 2: & 3: & 4: & 5: & 6: \\
\hline \multirow[t]{2}{*}{ Income pc (log) } & 0.108 & 0.012 & -0.009 & -0.069 & -0.078 & -0.081 \\
\hline & $(0.315)$ & $(0.312)$ & $(0.340)$ & $(0.311)$ & $(0.310)$ & $(0.313)$ \\
\hline \multirow[t]{2}{*}{ Financial depth } & 0.003 & 0.002 & 0.004 & 0.002 & 0.002 & 0.003 \\
\hline & $(0.003)$ & $(0.002)$ & $(0.003)$ & $(0.002)$ & $(0.002)$ & $(0.002)$ \\
\hline \multirow[t]{2}{*}{ Inequality } & 0.005 & 0.009 & 0.012 & 0.009 & 0.009 & 0.009 \\
\hline & $(0.014)$ & $(0.014)$ & $(0.013)$ & $(0.015)$ & $(0.014)$ & $(0.014)$ \\
\hline \multirow[t]{2}{*}{ Right ideology } & -0.034 & 0.068 & -0.038 & 0.044 & 0.047 & 0.044 \\
\hline & $(0.195)$ & $(0.204)$ & $(0.201)$ & $(0.203)$ & $(0.204)$ & $(0.204)$ \\
\hline \multirow[t]{2}{*}{ Parliamentary dem. } & 0.027 & 0.133 & 0.088 & 0.090 & 0.078 & 0.092 \\
\hline & $(0.270)$ & $(0.278)$ & $(0.220)$ & $(0.283)$ & $(0.280)$ & $(0.284)$ \\
\hline Leader's age & $\begin{array}{c}-0.019 * * \\
(0.009)\end{array}$ & $\begin{array}{c}-0.015+ \\
(0.008)\end{array}$ & $\begin{array}{c}-0.016+ \\
(0.009)\end{array}$ & $\begin{array}{c}-0.015+ \\
(0.008)\end{array}$ & $\begin{array}{c}-0.015+ \\
(0.008)\end{array}$ & $\begin{array}{c}-0.015+ \\
(0.008)\end{array}$ \\
\hline \multirow[t]{2}{*}{ Business career } & $0.906 * * *$ & $0.910 * * *$ & $0.981 * * *$ & $0.908 * * *$ & $0.904 * * *$ & $0.908 * * *$ \\
\hline & $(0.230)$ & $(0.235)$ & $(0.236)$ & $(0.233)$ & $(0.231)$ & $(0.231)$ \\
\hline \multirow[t]{2}{*}{ Anglo-Saxon countries } & $1.105 * * *$ & $1.150 * * *$ & $1.173 * * *$ & $1.219 * * *$ & $1.217 * * *$ & $1.213 * * *$ \\
\hline & $(0.213)$ & $(0.215)$ & $(0.207)$ & $(0.220)$ & $(0.218)$ & $(0.218)$ \\
\hline \multirow[t]{2}{*}{ Growth over tenure } & & $0.038 * * *$ & $0.019 * *$ & $0.037 * * *$ & 0.014 & 0.010 \\
\hline & & $(0.008)$ & $(0.006)$ & $(0.008)$ & $(0.027)$ & $(0.029)$ \\
\hline Growth over world growth & $\begin{array}{c}0.019 * * \\
(0.008)\end{array}$ & - & - & - & - & - \\
\hline Spending $\triangle$, levels & - & $\begin{array}{c}-0.008 * * \\
(0.003)\end{array}$ & - & $\begin{array}{c}-0.012 \\
(0.011)\end{array}$ & $\begin{array}{c}-0.007 * * \\
(0.003)\end{array}$ & $\begin{array}{c}-0.007 \\
(0.010)\end{array}$ \\
\hline Discretionary spending & - & - & $\begin{array}{c}-0.043 * * \\
(0.021)\end{array}$ & - & - & - \\
\hline Political constraints & - & - & - & $\begin{array}{c}0.474 \\
(0.837)\end{array}$ & $\begin{array}{c}0.253 \\
(0.751)\end{array}$ & $\begin{array}{c}0.201 \\
(0.787)\end{array}$ \\
\hline Pol. constraints $\times$ Spending $\triangle$ & - & - & - & $\begin{array}{c}0.011 \\
(0.025)\end{array}$ & - & $\begin{array}{c}0.004 \\
(0.025)\end{array}$ \\
\hline Pol. constraints $\times$ Growth & - & - & - & - & $\begin{array}{c}0.052 \\
(0.059)\end{array}$ & $\begin{array}{c}0.070 \\
(0.067)\end{array}$ \\
\hline Growth $\times$ Spending $\triangle$ & - & - & - & - & - & $\begin{array}{c}0.000 \\
(0.000)\end{array}$ \\
\hline Pol. constraints $\times$ Growth $\times$ Spending $\triangle$ & - & - & - & - & - & $\begin{array}{c}-0.001 \\
(0.001)\end{array}$ \\
\hline Constant & $\begin{array}{c}-1.236 \\
(1.446)\end{array}$ & $\begin{array}{c}-1.357 \\
(1.459)\end{array}$ & $\begin{array}{c}-1.452 \\
(1.549)\end{array}$ & $\begin{array}{c}-1.218 \\
(1.487)\end{array}$ & $\begin{array}{c}-1.103 \\
(1.458)\end{array}$ & $\begin{array}{l}-1.127 \\
(1.465)\end{array}$ \\
\hline$\overline{\mathrm{N}}$ & 437 & 446 & 354 & 445 & 445 & 445 \\
\hline $\mathrm{N}$ countries & 87 & 87 & 82 & 86 & 86 & 86 \\
\hline Log-likelihood & -143.431 & -146.867 & -114.889 & -146.355 & -146.077 & -145.865 \\
\hline
\end{tabular}

Table 2: Business Careers of Former Leaders, Spending and Constraints in Office Note: All estimations exclude leaders who retired, went into exile, were arrested or jailed after leaving office. The choice of occupation is compared with other "active pursuits". Inequality is estimated via probit regression with multiple imputation. Models 1-6 are probit regression models with standard errors clustered by country. $+\mathrm{p}<0.10, * * \mathrm{p}<0.05, * * * \mathrm{p}<0.01$. 

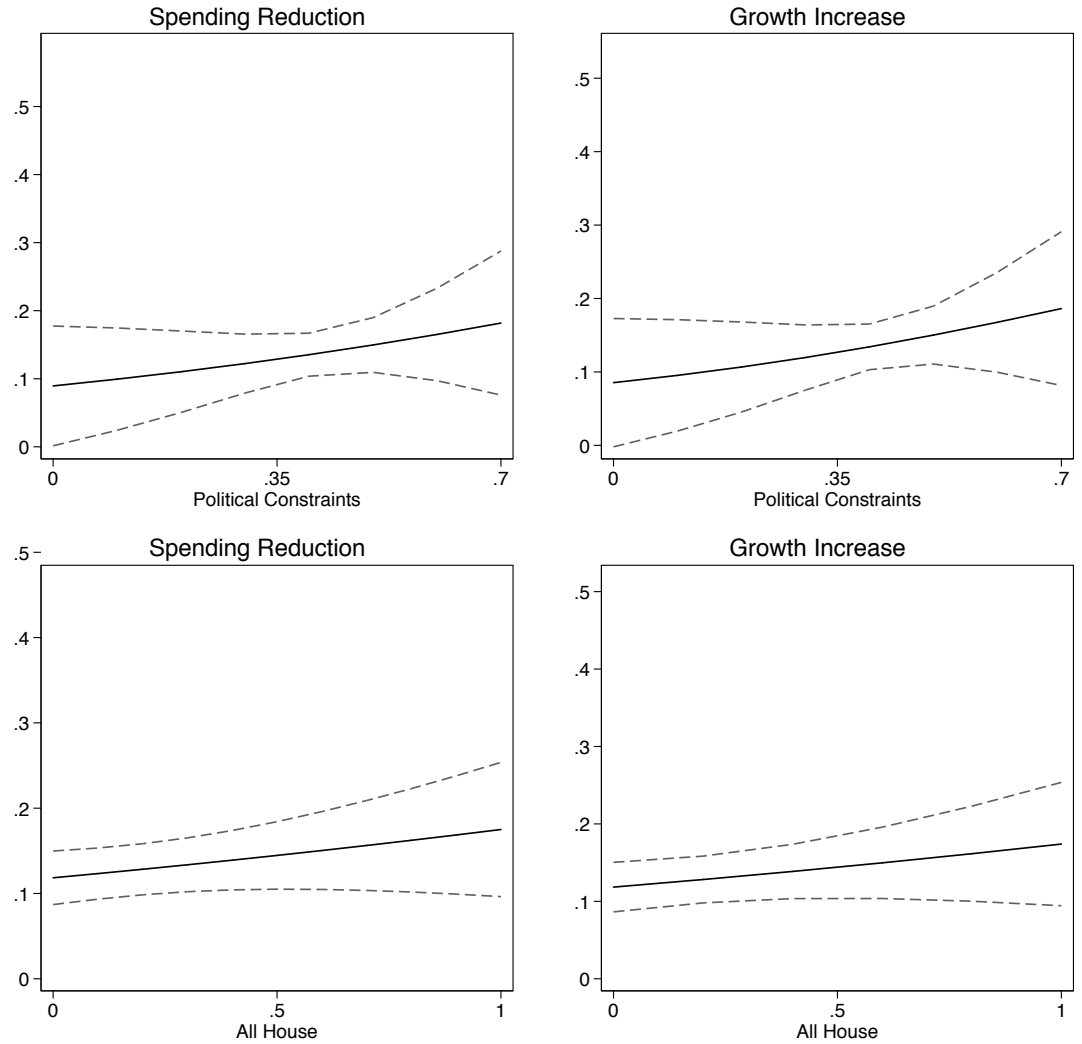

Spending Reduction

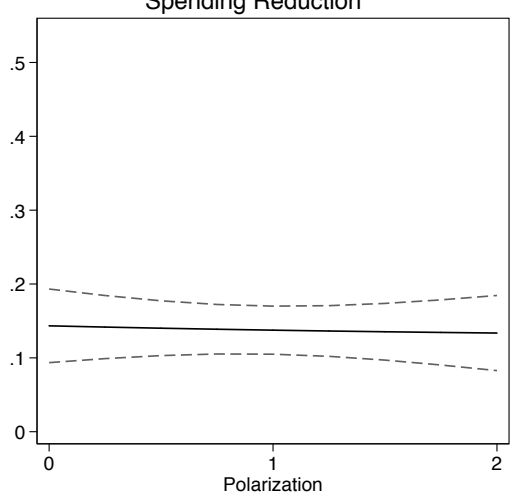

Spending Reduction

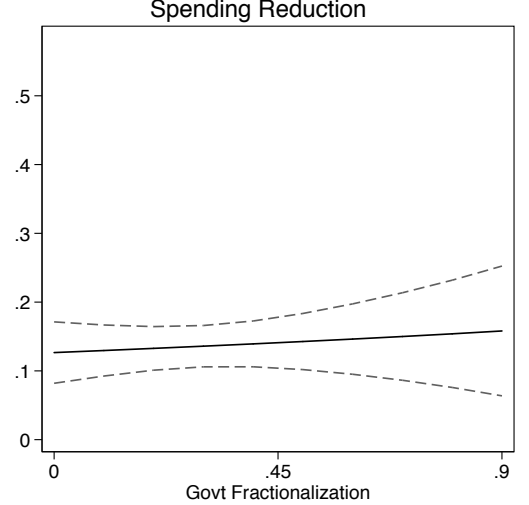

Growth Increase

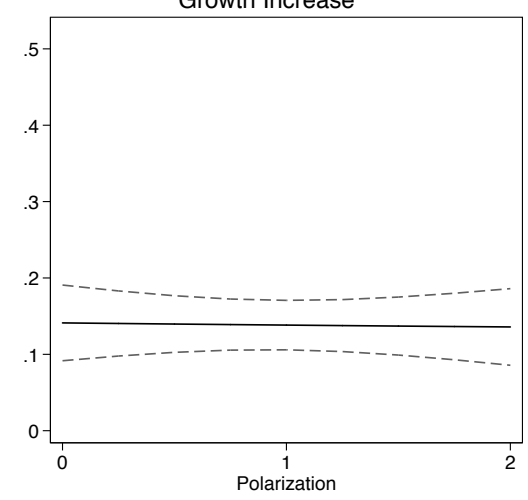

Growth Increase

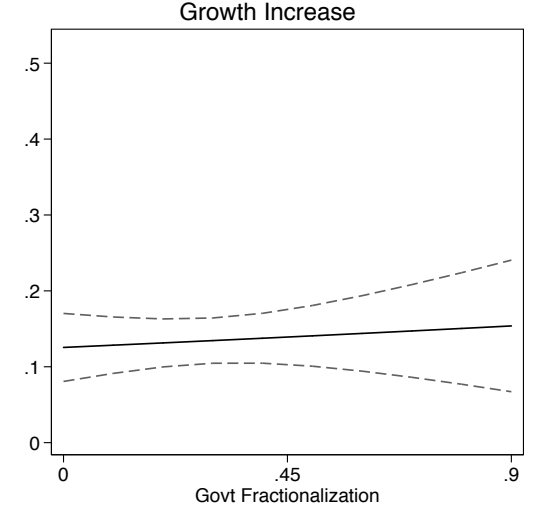

Figure 2: Are Leaders (Really) Responsible for Economic Outcomes? Constraints, Performance, and Business Careers. Note: Predicted probabilities of business careers are estimated following a series of interaction models, using margins in Stata. Graphs in the left column display probabilities of business career when Spending $\triangle$ is fixed at -2 standard deviations below the mean, over the range of 4 different indicators for constraints in office, separate estimations. Similarly, graphs on the right display probabilities when Growth over tenure is fixed at +2 standard deviations above the mean, over the range of 4 indicators. First row reports Models 4-5, Table 2, second to fourth rows display results estimated from auxiliary models in supplementary materials. 


\title{
Supplementary Materials to Blair Disease? \\ Business Careers of the Former Democratic Heads of State and Government
}

\begin{abstract}
The appendix provides details about the variables employed in the empirical analyses, including Table 1 of summary statistics. The second section explains the estimation of discretionary spending that accounts for cyclicality in governmental spending. The appendix also includes additional and sensitivity analyses, as explained in the paper. Firstly, Table 2 explains marginal effects following the "full" model in the paper, while Table 3 replicates the results using the fixed-effects specification and Table 4 replicates interactive models using discretionary spending instead of changes in spending. Table 5 includes several model specifications with alternative operationalization of the dependent variable and different estimation sample. Table 6 includes results with additional indicators for performance in office and "pro-business" policies. Also, the same table includes IV-models. Table 7 includes alternative specifications of inequality, CEO compensation, and societal norms. Finally, Table 8 fully reports several interactive models based on which the marginal effects were plotted in the paper.
\end{abstract}




\section{Descriptive Statistics}

Table 1 reports the average, standard deviation, minimum and maximum values, as well as the total number of observations for the dependent variables, leaders' prior careers and personal characteristics, as well as various political and economic indicators employed throughout the paper and supplementary analyses.

Income per capita, log is a logarithm of rgdpl at the time of exit from office (Heston, Summers and Aten, 2012), Financial depth (GFDD.DI.01, Global Financial Development Database, November 2013 version), Inequality measured as Gini index of inequality in equivalized (square root scale) household disposable (post-tax, post-transfer) income, using Luxembourg Income Study data as the standard, sourced from SWIID (Version 5.0) data that uses a custom missing-data multiple-imputation algorithm to standardize observations collected from various sources (Solt, 2009). Parliamentary democracy (Beck et al., 2001) [extended for 1960-74], Income equality, WVS, Private business, WVS and Wealth accumulation, WVS (the World Values Survey, 1981-2014) ${ }^{1}$, Growth in last year (Heston, Summers

${ }^{1}$ Income equality, WVS, Private business, WVS and Wealth accumulation, WVS are from the World Values Survey, 1981-2014, available at www.worldvaluessurvey.org/ WVSContents.jsp. Income equality V96: Income equality where 1 is "Incomes should be made more equal" and 10 "We need larger income differences as incentives for individual effort." Business ownership is V97: Private vs state ownership of business, where 1 is "Private ownership of business and industry should be increased" and 10 "Government ownership of business and industry should be increased." Wealth accumulation is V101: Wealth accumulation that ranges from "People can only get rich at the expense of others" to "Wealth can grow so there's enough for everyone." We invert the values of Business ownership so that higher values stand for pro-business attitudes in both variables. We calculate the average value for a year or wave of the survey per country. For the missing years we use the closest 
and Aten, 2012), Capital share (UNIDO, 2010) and Top 10 share - Income share held by highest 10 per cent (World Development Indicators) are variables with values at the last year in office.

Political constraints (Henisz, 2002), All house, Governmental fractionalization, Polarization (Beck et al., 2001), and Deficit over tenure (World Development Indicators Online) record average values of these variables for leader's time in office.

Business career, Prior business career, Years in politics, Leaders' age, Ex finance minister, Economics degree are time invariant indicators (Baturo, 2014). Right ideology is based on execrlc indicator from (Beck et al., 2001), category "Right" (1). The coverage is additionally extended to cover 1960-1974 so that parties coded as right by DPI after 1975 are coded as right for the earlier period. Years in politics: only years in official politics prior to assuming the highest office are counted, such as being a member of parliament, cabinet minister, province governor, city mayor, or member of a sub-national parliament. Anglo-Saxon countries takes the value of one if a country is United States, United Kingdom, Canada, Australia, New Zealand.

Spending ch., levels (Heston, Summers and Aten, 2012) is percentage increase in state spending levels between first and last years in office. Spending change (Heston, Summers and Aten, 2012), Econ. freedom change, Invest. freedom change (the 2014 Index of Economic Freedom), ${ }^{2}$ Trade openness change (Heston, Summers and Aten, 2012) are changes available date available for a country. E.g., if Argentina has observations for 2006, 1999, 1995, etc, we use values from 2006 for 2000-2005, of 1999 for 1996-98, etc, down to 1981.

${ }^{2}$ The 2014 Index of Economic Freedom, available from http://www.heritage.org/ index/download, accessed 15 February 2014. The 2014 Index is released in November of 2013 so that 2014 rankings cover the second half of 2012 and early 2013. In the analyses, therefore, we lag the scores by 2 years. 
in the values of these variables between first and last years in office. Growth over tenure (Heston, Summers and Aten, 2012) is percentage increase in GDP per capita between first and last years in office. Spending at entry (Heston, Summers and Aten, 2012) records the value for the first year in office. Discretionary spending is explained in more detail below.

\section{[TABLE 1 ABOUT HERE]}

\section{Discretionary spending}

Fatás and Mihov (2003) suggest that fiscal policy can be viewed as consisting of three components: (a) automatic stabilizers, (b) discretionary fiscal policy that is devised in reaction to the state of the economy, and (c) discretionary policy that is driven by reasons unrelated to current macroeconomic conditions. The last component of fiscal policy is more likely to be under leaders? control since it captures changes in the cyclically-adjusted fiscal policy stance. Although there is no consensus on the exact measure of discretionary fiscal policy (see e.g. Alesina and Perotti, 1996; Blanchard, 1993), given the cross-national nature of our data we follow the approach proposed in recent work on fiscal policy (Fatás and Mihov, 2003, 2006; Afonso, Agnello and Furceri, 2010; Agnello, Furceri and Sousa, 2013).

For our measure of government discretionary spending, we estimate for each country $i$ (with $i=1, \ldots, N$ ) over the period 1960-2010, the following fiscal policy rule:

$$
\Delta G_{i, t}=\alpha_{i}+\beta_{i} \Delta Y_{i, t}+\gamma_{i} \Delta G_{i, t-1}+\delta_{i} \mathbf{W}_{i, t}+\varepsilon_{i, t}
$$

where $G$ is the logarithm of real government consumption, $Y$ is the logarithm of real GDP, and $\mathbf{W}$ is a set of controls. As controls we include inflation, inflation squared, a time trend and the logarithm of oil prices. The latter is included following Fatás and Mihov (2003)'s suggestion that the revenues of some countries may heavily rely on oil tax revenues, in addition to a more general effect of oil prices on the economy. The linear time trend aims 
to capture the deterministic trend in the evolution of government spending. Inclusion of inflation is justified on the grounds that some spending items are automatically indexed to inflation, and to capture high inflation episodes. We interpret the residual of the model $\varepsilon_{i, t}$ as a quantitative estimate of discretionary policy. Fatás and Mihov (2003) argue that this approach is similar to, and highly correlated with, several alternative approaches to estimating discretionary spending (e.g. Alesina et al., 2002; Blanchard and Perotti, 2002). We view the discretionary component of government spending as a measure that is separated from the business cycle, and as such it reflects unexpected variation in fiscal policy.

Given that we include current value of economic growth $\left(\Delta Y_{i, t}\right)$, we use lagged values as instrumental variables to avoid the possibility of endogeneity bias. Current growth is instrumented with two lags of GDP growth, logarithm of oil prices, and lagged inflation. The main model also includes, as additional controls, a linear time trend, inflation, and inflation squared (to capture the potential non-linear relationship between spending and inflation).

The data on GDP and government spending comes from Penn World Tables (Heston, Summers and Aten, 2012) and is discussed in the data description section. Inflation data is taken from World Development Indicators GDP deflator series [NY.GDP.DEFL.KD.ZG]. Oil prices are inflation-adjusted dollars per barrel prices for Illinois Crude that is trending West Texas Intermediate from http://inflationdata.com/Inflation/Inflation_ Rate/Historical_Oil_Prices_Table.asp (last accessed 7 July 2015).

\section{Supplementary and Sensitivity Analyses}

Estimation of Marginal Effects: In the interest of space, marginal effects - following Table 1 in the main paper — were only briefly discussed. For additional information on substantive effects we can also look at the predictive margins in more detail. Table 2 presents 
the effects of two variables that account for the likely attractiveness of the business sector the benchmark of CEO compensation and Anglo-Saxon indicator - and two variables that account for leaders' traits and attractiveness - growth over tenure and their prior business career - estimated following model 3, Table 1 in the main paper. Holding other predictors at their means, we examine the predicted probability of business career at low and high values of these predictors. When the variables are fixed at -2 standard deviations below their average or at their minimum values, the probability of a business career is effectively null, as seen in the right column. The probability increases at high values of predictors, particularly for the Anglo-Saxon countries at 40 per cent. We also distinguish if the personal attributes of leaders matter. The first two columns report predicted probabilities for the same predictors, separately for leaders with and without prior business careers. The likelihood of a future business career for former businessmen is 47 per cent in a highly performing economy, 69 per cent in the Anglo-Saxon one, and 43 per cent when CEO compensation is high, as opposed to 17,35 and 14 percent for leaders without such careers. Finally, we assess the substantive effects of the predictors fixed at low or high values simultaneously: the probability of a business career becomes almost certain, at 92 per cent, for leaders with prior private sector experience; it is also at 70 per cent for those without.

Supplementary Analyses for Table 2: Model 4 in Table 1 in the main paper was specified as a conditional logit controlling for time invariant country specific characteristics. Because fixed-effects specification results in a considerable loss of observations that are dropped from the estimation whenever either all or no leaders go into the private sector, in addition to any other time invariant variables like parliamentary democracy and AngloSaxon countries, we relied on a simpler probit model with cluster-robust standard errors in Table 2. As an additional test, Table 3 replicates Table 2 of the main paper, however the 
models are specified as conditional logit with time invariant country effects.

Models 4-6 in Table 2 of the main paper include Spending $\triangle$, levels and growth interacted with political constraints. As an additional test, Table 4 interacts Discretionary spending with political constraints instead. As earlier, the results point in the direction of either weak or no effect. We interpret these findings to indicate that leaders who foresee a business career in the future do not implement specific policies with such careers in mind.

\section{[TABLE 2 ABOUT HERE] \\ [TABLE 3 ABOUT HERE] \\ [TABLE 4 ABOUT HERE]}

The Sample and the Dependent Variable: Table 5 includes several sensitivity studies following two model specifications from the main paper each: Model 3 (Table 1) and Model 2 (Table 2), i.e., "full" model that includes structural conditions and individual traits, and "performance in office" model.

Model specifications in the paper predict business careers versus all other careers. As a sensitivity test, Models 1-2 predict future political careers versus other types of careers, including business careers. There are 75 , or 14 percent of leaders who turn to business careers and 384 or 65 percent of leaders who remain in politics. The remaining 22 percent of leaders are engaged in other pursuits. In contrast to the model that predicts future business careers, Models 1-2 suggest that those who can return to the office of the head of government (in parliamentary democracy) are more likely to remain in politics than pursue any other occupations. There is no evidence that those who were more successful in managing the economy (Growth) are more likely to remain in politics. As another sensitivity test, models 3-4 are fitted on a sample that predicts business careers versus political careers only, excluding other possible pursuits (e.g., international career, civil service). While the estima- 
tion sample is reduced by about a quarter, the results remain relatively stable. As explained in the paper, the categories of business and political careers are not always mutually exclusive. Altogether, in the estimation sample there are 16 leaders, or three percent, who are categorized in both politics and business at the same time. As a test of sensitivity, Models 5-6 exclude rulers who pursued two careers at the same time.

\section{[TABLE 5 ABOUT HERE] [TABLE 6 ABOUT HERE] [FIGURE 1 ABOUT HERE]}

Does the inclusion of interim leaders and leaders who serve a very short time in office influence the results? Altogether, 17 percent of all rulers in the estimation sample served one year in office or an even shorter period. It is conceivable that the post-office careers of longer serving leaders are different from those who stay in office for a short period of time. More accomplished leaders might find it easier to pursue other activities in nonprofit or business sectors, for example because of connections made in office. Additionally, for leaders serving tenures of one year or less, the value of the spending change variable, because it is calculated as the difference between spending level at the entry and exit to and from office for each particular leader, is recorded as 0 . In order to test whether results are affected by the exclusion of short-term leaders, Models $7-8$ in Table 5 predict the probability of rulers' who served one year or less choosing business careers. Additionally, while many leaders choose business careers after leaving office over the 1960-2010 period, the number doing so in 2000-2010 was higher than in preceding decades. To test whether the results are driven by leaders who choose to work for the private sector in 2000s, Models 9-10 are fitted on a sample that excludes such leaders, and only includes leaders departing from office in the 1960-1999 period. However, the results are not affected by the choice to reduce the 
sample size as can be seen in columns on the right.

Alternative Indicators for Economic Performance: Results are fully reported below in Table 6, Figure 1 displays the coefficients of five separate model specifications: changes in Economic freedom index and Trade openness between final and first year in office are statistically significant predictors of leaders' business careers, similarly to changes in Spending — estimated as difference in state spending as percentage of GDP ( $\mathrm{kg}$ in Heston, Summers and Aten (2012)).

Table 6 has several alternative model specifications. As discussed in the paper, we considered alternative measures of performance in office that can be assessed by the markets. We used changes in the Economic freedom index between final and first year in office, and changes in Investment freedom. Both indicators are sourced from the Heritage foundation. In both the composite Economic freedom and more specific Investment freedom indices higher values stand for more economic and investment freedom, therefore the coefficients on these variables are expected to have the opposite direction of effects than the coefficient on spending. As can be seen, leaders under whose watch national economic rankings seemingly improved are more likely to pursue business careers. However, while investment rankings change has the expected direction of effects, it is not statistically significant. ${ }^{3}$

Our third model includes yet another indicator that is potentially attractive to the markets: changes in trade openness during tenure. Evidently, leaders who increase trade - or happen to serve in office at a time when trade regime becomes more liberal - are more

${ }^{3}$ The index covers only more recent time period and not all the countries that are included in the analyses of this paper, however. Likewise, this index is not unrelated to the overall measures of democracy and development, and even to state spending levels. On possible endogeneity in the expert surveys, see for example Glaeser et al. (2004). 
likely to pursue business careers after office. Likewise, we include an indicator for budget deficit or surplus, averaged over leader tenure in the fourth model, however this predictor is not statistically significant. The results should be treated with caution, however, since the inclusion of deficit indicator greatly reduces the estimation sample. The fifth model includes a cruder measure of changes in state spending — changes in spending as a proportion of GDP as opposed changes in the total level of spending over tenure used in the paper.

IV-estimation: The relationship between spending, economic growth and the careers of rulers can be more complicated than posited. While right-of-center former leaders can be arguably more likely to pursue business career opportunities, it is also possible that rulers who believe in the restricted role of the state will be more likely to contract the public sector size, while left-leaning leaders will do the opposite. Many parties, especially on the right, favor spending cuts for ideological reasons (Pierson and Smith, 1993, 500). If ideology can influence higher governmental spending, then the former will exert its effects on the probability of a business career indirectly via its shared variability with spending. Likewise, while rulers can simultaneously reduce spending and preside over economic growth, periods of economic recession and low economic growth can make it more difficult to increase governmental spending. It is also conceivable that leaders with low economic growth in their last years in office will be less attractive to the markets and less likely to find private employment.

To address these issues, we can include economic growth in final year in office and governmental spending at the time of entry into office as weak instruments for changes in the relative size of the public sector. All things being equal, low governmental spending at the time of entry into office makes it more likely that spending can be increased further as a proportion of GDP, in contrast to economies where the size of the state is already 
very large. At the same time, entry spending should not affect the probability of business careers directly, rendering it a valid instrument. We report the results of the instrumentalvariables probit model in columns 6 and 7 of Table 6, with Spending $\triangle$ and Spending $\triangle$, levels instrumented by Entry spending and Growth in the last year in office. Both indicators of spending remain statistically significant in two specifications. The coefficients retain the same direction of effects as in the ordinary probit model. In the first model the null hypothesis of exogeneity can be rejected, but only at the 0.1 level, indicating that spending in office is somewhat affected by Entry spending and the previous year's Growth.

\section{[TABLE 7 ABOUT HERE] [TABLE 8 ABOUT HERE]}

Inequality: There are several general measures to compare inequality across nations. The most commonly used, the Gini coefficient, maps the cumulative percentage of income in a population versus the cumulative percentage of individuals in a population on a scale from zero to one where perfectly equal societies would have the zero coefficient. Another measure, based on the functional distribution of income - capital income share - is another candidate to account for economic inequality. Capital share of industry value-added should serve as a good proxy for the degree of inequality because capital income tends to accumulate in the hands of a small rich elite, while the poor classes rely on income from labor, so higher capital share will stand for higher inequality (Acemoglu and Robinson 2006, 59; Przeworski et al. 2000, 121). Capital income share is constructed as one minus the ratio of total wages and salaries in manufacturing to total value-added in manufacturing (UNIDO, 2010). Likewise, we can use percentage of GDP that accrues to the top 10 percent of the population as another indicator for inequality. Models 1-2 in Table 7 replicates Model 1, Table 1 in the main paper using these two alternative measures of inequality. While Income 
of the top 10 share is a statistically significant predictor of the likelihood of leaders' business careers, albeit at 0.1 level of significance, capital share is not statistically significant. Both model specifications suffer from significant degree of missingness as well.

CEO Compensation: In the paper, we rely on Economic Policy Institute's annual figures for average CEO compensation of the top 350 firms and that includes the value of stock options exercised in a given year. ${ }^{4}$ Because the data extended to 1965 and no comparative datasets are available, we rely on those estimates. Model 3 in Table 7 includes an indicator for CEO compensation sourced from the same data but measured as the average in the last three years before leaving office, for each leader. As an alternative indicator, we also source executive compensation figures from the S\&P ExecuComp dataset, 1992-2014. ${ }^{5}$ While both indicators for executive compensation have the correct direction of effects, only CEO pay, 3-year average is statistically significant. While CEO pay, ExecuComp is a superior source of executive compensation, it is available for a much shorter period starting in 1992 only however.

Cultural Norms: Model 5, Table 7 includes the survey indicators for societal attitudes about inequality and the value of business activity as additional controls for cultural norms.

${ }^{4}$ http://www.epi.org/publication/ceo-pay-2012-extraordinarily-high/, accessed 7 July 2015. The data are compiled from Compustat's ExecuComp database, Federal Reserve Economic Data (FRED) from the Federal Reserve Bank of St. Louis, the Current Employment Statistics program, and the Bureau of Economic Analysis NIPA tables.

${ }^{5} \mathrm{CEO}$ compensation is TDC1 (table: AnnComp), measured as Total Compensation (Salary + Bonus + OtherAnnual + RestrictedStockGrants + LTIPPayouts + AllOther + Valueof OptionGrants). We select TDC1 for those designated as CEO in CEOANN (table: AnnComp), and calculate average TDC1 for the top 100 companies based on the number of employees each year (EMPL (table: Codirfin), in thousands. 
In the paper the available country observations were extended back in time down to the next available observation in the previous survey wave, and so on down to the first year surveyed in 1981. As a test of sensitivity, here we extend observations by only three years from the available observation. While it somewhat reduces the estimation dataset, results remain comparable to those in the paper.

Alternative Indicators for Constraints: In the paper, as a test examining whether leaders who preside over economic growth and a reduction in state spending, and who pursue private careers in retirement, have some degree of responsibility for these outcomes, we interacted political constraints indicator, averaged over leader's tenure, with changes in spending and economic growth. Results indicate that less constrained leaders who preside over spending reduction or growth increase are no more likely to be attracted to the private sector in retirement. As a test of sensitivity, Table 8 additionally includes three different measures of constraints on the ability of the executive to implement policies. For additional constraints measures we used data from Beck et al. (2001) on whether the executive party controls all relevant legislative chambers (All House); maximum difference of orientation between the executive party and the four principle parties of the legislature, Polarization; and governmental fractionalization, the chance that two random draws will produce legislators from different parties, Govt fractionalization. As in the paper, each of these constraint indicators is averaged over leader's tenure and interacted with both economic variables separately, and together with all multiplicative interaction terms (e.g., see Braumoeller, 2004). 


\section{References}

Acemoglu, Daron and James Robinson. 2006. Economic Origins of Dictatorship and Democracy. Cambridge; New York: Cambridge University Press.

Afonso, António, Luca Agnello and Davide Furceri. 2010. "Fiscal policy responsiveness, persistence, and discretion." Public Choice 145(3-4):503-530.

Agnello, Luca, Davide Furceri and Ricardo M Sousa. 2013. "How best to measure discretionary fiscal policy? Assessing its impact on private spending." Economic Modelling $34: 15-24$.

Alesina, Alberto and Roberto Perotti. 1996. "Fiscal expansions and fiscal adjustments in OECD countries." Economic Policy 21:205-240.

Alesina, Alberto, Silvia Ardagna, Roberto Perotti and Fabio Schiantarelli. 2002. "Fiscal Policy, Profits, and Investment." The American Economic Review 92(3):571-589.

Baturo, Alexander. 2014. Democracy, Dictatorship, and Term Limits. Ann Arbor, MI: Michigan University Press.

Beck, Thorsten, George Clarke, Alberto Groff, Philip Keefer and Patrick Walsh. 2001. "New Tools in Comparative Political Economy: The Database of Political Institutions." World Bank Economic Review 15:165-176.

Blanchard, Olivier Jean. 1993. Suggestions for a new set of fiscal indicators. In The New Political Economy of Government Debt, ed. H.A.A. Verbon and F.A.A.M. van Winden. Elsevier.

Blanchard, Olivier and Roberto Perotti. 2002. "An Empirical Characterization of the Dynamic Effects of Changes in Government Spending and Taxes on Output." Quarterly Journal of Economics 117(4):1329-1368.

Braumoeller, Bear. 2004. "Hypothesis Testing and Multiplicative Interaction Terms." International Organization 58:807-820.

Fatás, Antonio and Ilian Mihov. 2003. "The Case for Restricting Discretionary Fiscal Policy." Quarterly Journal of Economics 118(4):1419-1447.

Fatás, Antonio and Ilian Mihov. 2006. "The Macroeconomic Effects of Fiscal Rules in the US States." Journal of Public Economics 90(1):101-117.

Glaeser, Edward, Rafael La Porta, Florencio Lopez de Silanes and Andrei Shleifer. 2004. “Do Institutions Cause Growth?” Journal of Economic Growth 9(3):271-303. 
Henisz, Witold. 2002. "The Institutional Environment for Infrastructure Investment.” Industrial and Corporate Change 11(2):334-363.

Heston, Alan, Robert Summers and Bettina Aten. 2012. "Penn World Table Version 7.1." Center for International Comparisons of Production, Income and Prices at the University of Pennsylvania.

Pierson, Paul and Miriam Smith. 1993. "Bourgeois Revolutions? The Policy Consequences of Resurgent Conservatism.” Comparative Political Studies 25(4):487-520.

Przeworski, Adam, Michael Alvarez, Jose Cheibub and Fernando Limongi. 2000. Democracy and Development: Political Institutions and Well-being in the World, 1950-1990. Cambridge; New York: Cambridge University Press.

Solt, Frederick. 2009. "Standardizing the World Income Inequality Database." Social Science Quarterly 90(2):231-242.

UNIDO. 2010. “INDSTAT4 - Industrial Statistics Database.” United Nations Industrial Development Organization. 


\begin{tabular}{|c|c|c|c|c|c|}
\hline Variable & Mean & Std. Dev. & Min. & Max. & $\mathbf{N}$ \\
\hline$\overline{\text { Business career }}$ & 0.136 & 0.343 & 0 & 1 & 551 \\
\hline Career in politics & 0.693 & 0.462 & 0 & 1 & 551 \\
\hline Income pc (log) & 4.002 & 0.438 & 2.674 & 4.693 & 545 \\
\hline Financial depth & 50.969 & 43.985 & 0.940 & 218.38 & 512 \\
\hline Inequality, SWIID & 35.015 & 9.656 & 18.505 & 66.242 & 473 \\
\hline CEO compensation & 5.813 & 4.915 & 0.807 & 16.5 & 518 \\
\hline Anglo-Saxon & 0.083 & 0.277 & 0 & 1 & 551 \\
\hline Right ideology & 0.417 & 0.494 & 0 & 1 & 551 \\
\hline Parliamentary dem. & 0.661 & 0.474 & 0 & 1 & 551 \\
\hline Leader's age & 58.332 & 9.52 & 31 & 90 & 551 \\
\hline (Prior) business career & 0.134 & 0.341 & 0 & 1 & 551 \\
\hline Years in politics & 14.701 & 10.379 & 0 & 45 & 549 \\
\hline Ex finance minister & 0.067 & 0.251 & 0 & 1 & 551 \\
\hline Economics degree & 0.187 & 0.39 & 0 & 1 & 551 \\
\hline Income equality, WVS & 5.434 & 1.017 & 3.477 & 7.763 & 265 \\
\hline Private business, WVS & 5.854 & 0.863 & 4.055 & 7.821 & 258 \\
\hline Wealth accumulation, WVS & 6.368 & 0.668 & 4.466 & 7.708 & 252 \\
\hline Growth over tenure & 8.736 & 14.986 & -40.328 & 113.085 & 538 \\
\hline Spending $\triangle$, levels & 32.892 & 76.838 & -71.597 & 1157.365 & 538 \\
\hline Growth over world growth & 2.299 & 12.582 & -106.785 & 87.777 & 521 \\
\hline Discretionary spending, average over tenure & 0.055 & 5.695 & -19.826 & 77.218 & 410 \\
\hline Political constraints & 0.424 & 0.143 & 0 & 0.708 & 545 \\
\hline All house, over tenure & 0.314 & 0.451 & 0 & 1 & 431 \\
\hline Governmental fractionaliz., over tenure & 0.287 & 0.282 & 0 & 0.893 & 434 \\
\hline Polarization, over tenure & 0.796 & 0.856 & 0 & 2 & 388 \\
\hline Econ. freedom change & 1.067 & 3.335 & -5.7 & 16.2 & 217 \\
\hline Invest. freedom change & 0.484 & 9.568 & -25 & 30 & 217 \\
\hline Deficit over tenure & -1.668 & 3.435 & -11.009 & 14.923 & 166 \\
\hline Trade openness change & 3.19 & 12.081 & -39.66 & 87.136 & 538 \\
\hline Spending $\triangle$ & -0.198 & 2.329 & -26.411 & 18.295 & 538 \\
\hline Entry spending & 8.640 & 4.81 & 0.801 & 51.594 & 538 \\
\hline Last year growth & 2.029 & 4.194 & -21.842 & 15.751 & 474 \\
\hline Top 10 share income, \% GDP & 31.205 & 8.290 & 20.14 & 51.69 & 143 \\
\hline Capital share & 0.602 & 0.139 & 0.099 & 0.978 & 381 \\
\hline CEO pay, last 3-year average & 5.667 & 4.734 & 0.807 & 15.333 & 502 \\
\hline CEO pay, ExecuComp & 10.831 & 4.080 & 3.524 & 19.703 & 301 \\
\hline
\end{tabular}

Table 1: Descriptive Statistics 


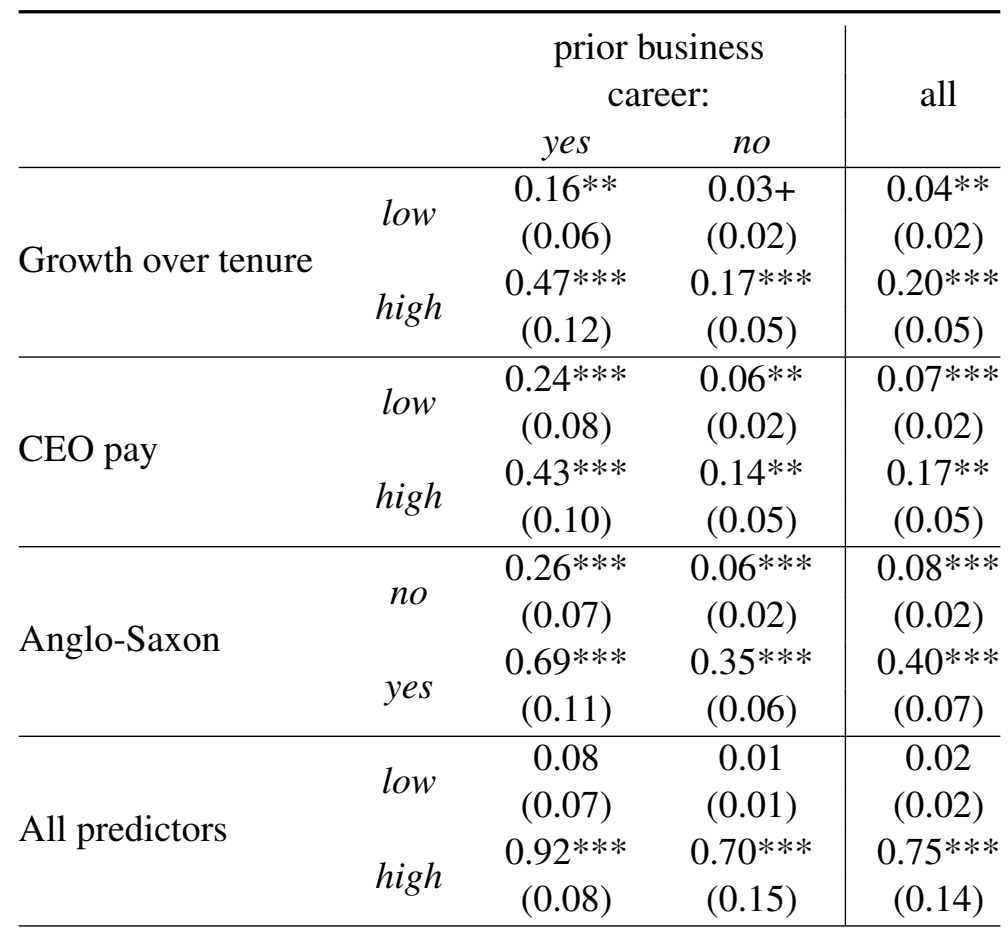

Table 2: Predicted Probabilities of Business Careers of Former Leaders Note: Predicted probabilities of business careers are estimated following Model 3, Table 1, using margins in Stata. Explanatory variables are fixed at -2 standard deviations (low) below the mean and +2 standard deviation above the mean (high), holding the values of other variables fixed at their means. Anglo-Saxon and CEO pay are fixed at minimum and maximum values. Standard errors of predictions are reported in parentheses. All predictors are Income pc (log), Inequality and Growth over tenure fixed at +2 standard deviations above the mean and Anglo-Saxon and CEO pay fixed at 0 and its minimum values simultaneously for high values. 


\begin{tabular}{|c|c|c|c|c|c|c|}
\hline & \multicolumn{3}{|c|}{ spending } & \multicolumn{3}{|c|}{ constraints } \\
\hline & 1: & 2: & 3: & 4: & 5: & 6: \\
\hline Income pc (log) & $\begin{array}{c}3.251 \\
(2.852)\end{array}$ & $\begin{array}{c}-0.738 \\
(3.138)\end{array}$ & $\begin{array}{c}-0.366 \\
(3.210)\end{array}$ & $\begin{array}{l}-0.815 \\
(3.114)\end{array}$ & $\begin{array}{c}-0.804 \\
(3.094)\end{array}$ & $\begin{array}{c}-0.855 \\
(3.052)\end{array}$ \\
\hline Financial depth & $\begin{array}{c}-0.004 \\
(0.008)\end{array}$ & $\begin{array}{c}0.002 \\
(0.011)\end{array}$ & $\begin{array}{c}0.005 \\
(0.009)\end{array}$ & $\begin{array}{c}0.002 \\
(0.011)\end{array}$ & $\begin{array}{c}0.002 \\
(0.011)\end{array}$ & $\begin{array}{c}0.002 \\
(0.010)\end{array}$ \\
\hline Inequality & $\begin{array}{l}0.126+ \\
(0.075)\end{array}$ & $\begin{array}{c}0.080 \\
(0.072)\end{array}$ & $\begin{array}{c}0.089 \\
(0.074)\end{array}$ & $\begin{array}{c}0.079 \\
(0.073)\end{array}$ & $\begin{array}{c}0.075 \\
(0.074)\end{array}$ & $\begin{array}{c}0.073 \\
(0.073)\end{array}$ \\
\hline Growth over world growth & $\begin{array}{c}0.052 * * \\
(0.025)\end{array}$ & & & & & \\
\hline Right ideology & $\begin{array}{l}-0.421 \\
(0.407)\end{array}$ & $\begin{array}{c}-0.463 \\
(0.467)\end{array}$ & $\begin{array}{c}-0.608 \\
(0.430)\end{array}$ & $\begin{array}{c}-0.505 \\
(0.478)\end{array}$ & $\begin{array}{c}-0.524 \\
(0.473)\end{array}$ & $\begin{array}{c}-0.534 \\
(0.468)\end{array}$ \\
\hline Leader's age & $\begin{array}{l}-0.026 \\
(0.028)\end{array}$ & $\begin{array}{c}-0.017 \\
(0.026)\end{array}$ & $\begin{array}{c}-0.005 \\
(0.026)\end{array}$ & $\begin{array}{l}-0.015 \\
(0.026)\end{array}$ & $\begin{array}{l}-0.015 \\
(0.026)\end{array}$ & $\begin{array}{l}-0.016 \\
(0.027)\end{array}$ \\
\hline Business career & $\begin{array}{c}1.336^{* *} \\
(0.529)\end{array}$ & $\begin{array}{c}1.410 * * \\
(0.519)\end{array}$ & $\begin{array}{c}1.350^{* *} \\
(0.538)\end{array}$ & $\begin{array}{c}1.430^{* *} \\
(0.515)\end{array}$ & $\begin{array}{c}1.470 * * \\
(0.533)\end{array}$ & $\begin{array}{c}1.507 * * \\
(0.547)\end{array}$ \\
\hline Spending $\triangle$, levels & & $\begin{array}{c}-0.029 * * * \\
(0.008)\end{array}$ & & $\begin{array}{l}-0.017 \\
(0.023)\end{array}$ & $\begin{array}{c}-0.031 * * * \\
(0.009)\end{array}$ & $\begin{array}{l}-0.050 \\
(0.033)\end{array}$ \\
\hline Growth over tenure & & $\begin{array}{c}0.095 * * * \\
(0.020)\end{array}$ & $\begin{array}{c}0.031 * * \\
(0.014)\end{array}$ & $\begin{array}{c}0.095^{* * *} * \\
(0.020)\end{array}$ & $\begin{array}{c}0.150 * * \\
(0.076)\end{array}$ & $\begin{array}{c}0.167 * * \\
(0.077)\end{array}$ \\
\hline Discretionary spending & & & $\begin{array}{c}-0.113 * * \\
(0.043)\end{array}$ & & & \\
\hline Political constraints & & & & $\begin{array}{c}1.509 \\
(2.229)\end{array}$ & $\begin{array}{c}1.872 \\
(2.156)\end{array}$ & $\begin{array}{c}1.967 \\
(2.288)\end{array}$ \\
\hline Pol. constraints $\times$ Spending $\triangle$ & & & & $\begin{array}{l}-0.029 \\
(0.061)\end{array}$ & & $\begin{array}{c}0.040 \\
(0.084)\end{array}$ \\
\hline Pol. constraints $\times$ Growth & & & & & $\begin{array}{l}-0.122 \\
(0.149)\end{array}$ & $\begin{array}{c}-0.160 \\
(0.163)\end{array}$ \\
\hline Growth $\times$ Spending $\triangle$ & & & & & & $\begin{array}{c}0.001 \\
(0.001)\end{array}$ \\
\hline Pol. constraints $\times$ Growth $\times$ Spending $\triangle$ & & & & & & $\begin{array}{c}-0.001 \\
(0.003)\end{array}$ \\
\hline $\mathrm{N}$ & 231 & 243 & 171 & 243 & 243 & 243 \\
\hline $\mathrm{N}$ countries & 32 & 33 & 28 & 33 & 33 & 33 \\
\hline Log-likelihood & -68.418 & -70.393 & -53.802 & -70.158 & -69.924 & -69.731 \\
\hline
\end{tabular}

Table 3: Business Careers of Former Leaders, Spending and Constraints in Office, Fixed Effects Note: This table replicates Table 2 in the paper with Models 1-6 as fixed-effects regression models. Time-invariant Anglo-Saxon and Parliamentary democracy are omitted. All estimations exclude leaders who retired, went into exile, were arrested or jailed after leaving office. The choice of occupation is compared with other "active pursuits". Inequality is estimated via probit regression with multiple imputation. $+\mathrm{p}<0.10$, ** $\mathrm{p}<0.05, * * \mathrm{p}<0.01$. ${ }^{a}$ Wald's test of exogeneity, probability of the null hypothesis of exogeneity. 


\begin{tabular}{|c|c|c|c|c|}
\hline & 3: & 4: & 5: & 6: \\
\hline \multirow[t]{2}{*}{ Income pc (log) } & -0.009 & -0.156 & -0.156 & -0.164 \\
\hline & $(0.340)$ & $(0.346)$ & $(0.350)$ & $(0.358)$ \\
\hline \multirow[t]{2}{*}{ Financial depth } & 0.004 & 0.004 & $0.004+$ & 0.004 \\
\hline & $(0.003)$ & $(0.003)$ & $(0.002)$ & $(0.003)$ \\
\hline \multirow[t]{2}{*}{ Inequality } & 0.012 & 0.012 & 0.013 & 0.014 \\
\hline & $(0.013)$ & $(0.013)$ & $(0.013)$ & $(0.013)$ \\
\hline \multirow[t]{2}{*}{ Right ideology } & -0.038 & -0.067 & -0.035 & -0.056 \\
\hline & $(0.201)$ & $(0.203)$ & $(0.209)$ & $(0.210)$ \\
\hline \multirow[t]{2}{*}{ Parliamentary dem. } & 0.088 & 0.009 & 0.016 & 0.047 \\
\hline & $(0.220)$ & $(0.223)$ & $(0.220)$ & $(0.217)$ \\
\hline Leader's age & $-0.016+$ & $\begin{array}{l}-0.015 \\
(0.009)\end{array}$ & $-0.015+$ & $-0.015+$ \\
\hline \multirow[t]{2}{*}{ Business career } & $0.981 * * *$ & $0.968 * * *$ & $0.954 * * *$ & $0.965 * * *$ \\
\hline & $(0.236)$ & $(0.232)$ & $(0.232)$ & $(0.235)$ \\
\hline \multirow[t]{2}{*}{ Anglo-Saxon } & $1.173 * * *$ & $1.309 * * *$ & $1.296 * * *$ & $1.295 * * *$ \\
\hline & $(0.207)$ & $(0.219)$ & $(0.216)$ & $(0.216)$ \\
\hline \multirow[t]{2}{*}{ Discretionary spending } & $-0.043 * *$ & -0.081 & $-0.040+$ & 0.036 \\
\hline & $(0.021)$ & $(0.116)$ & $(0.022)$ & $(0.161)$ \\
\hline \multirow[t]{2}{*}{ Growth over tenure } & $0.019 * *$ & $0.021 * *$ & -0.003 & 0.001 \\
\hline & $(0.006)$ & $(0.007)$ & $(0.016)$ & $(0.026)$ \\
\hline \multirow[t]{2}{*}{ Political constraints } & & 1.409 & 0.585 & 0.887 \\
\hline & & $(0.979)$ & $(0.885)$ & $(0.952)$ \\
\hline \multirow[t]{2}{*}{ Pol. constraints $\times$ Discretionary spending } & & 0.086 & & -0.157 \\
\hline & & $(0.234)$ & & $(0.319)$ \\
\hline \multirow[t]{2}{*}{ Pol. constraints $\times$ Growth } & & & 0.060 & 0.054 \\
\hline & & & $(0.040)$ & $(0.059)$ \\
\hline \multirow[t]{2}{*}{ Growth $\times$ Discretionary spending } & & & & -0.016 \\
\hline & & & & $(0.012)$ \\
\hline \multirow[t]{2}{*}{ Pol. constraints $\times$ Growth $\times$ Discretionary spending } & & & & 0.033 \\
\hline & & & & $(0.026)$ \\
\hline \multirow[t]{2}{*}{ Constant } & -1.452 & -1.491 & -1.240 & -1.367 \\
\hline & $(1.549)$ & $(1.626)$ & $(1.577)$ & $(1.655)$ \\
\hline$\overline{\mathrm{N}}$ & 354 & 354 & 354 & 354 \\
\hline $\mathrm{N}$ countries & 82 & 82 & 82 & 82 \\
\hline Log-likelihood & -114.889 & -113.723 & -113.027 & -111.916 \\
\hline
\end{tabular}

Table 4: Discretionary Spending and Constraints in Office Note: All estimations exclude leaders who retired, went into exile, were arrested or jailed after leaving office. The choice of occupation is compared with other "active pursuits". Inequality is estimated via probit regression with multiple imputation. Models 3-6 are probit regression models with robust-clustered standard errors. $+\mathrm{p}<0.10, * * \mathrm{p}<0.05, * * * \mathrm{p}<0.01$. 


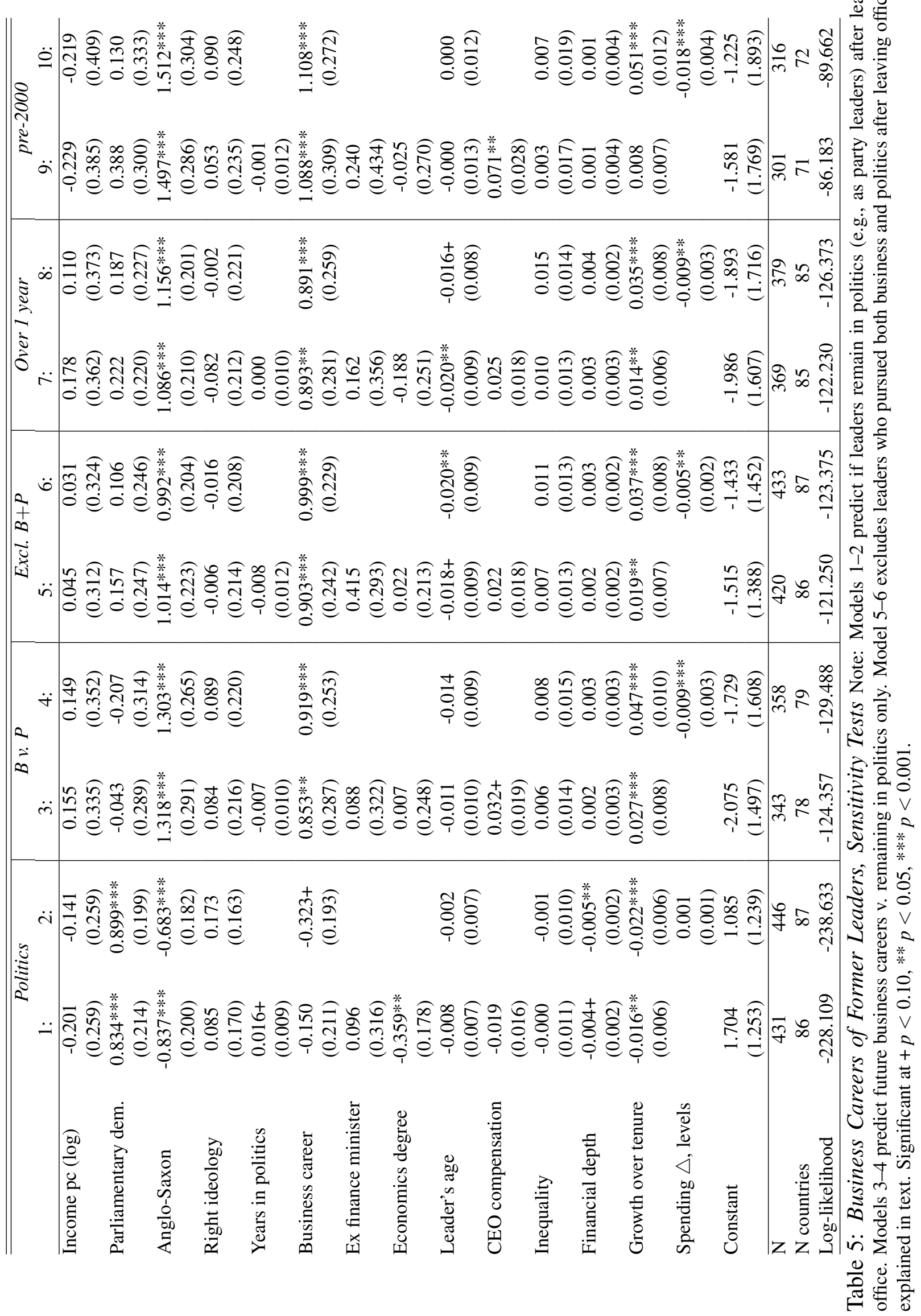




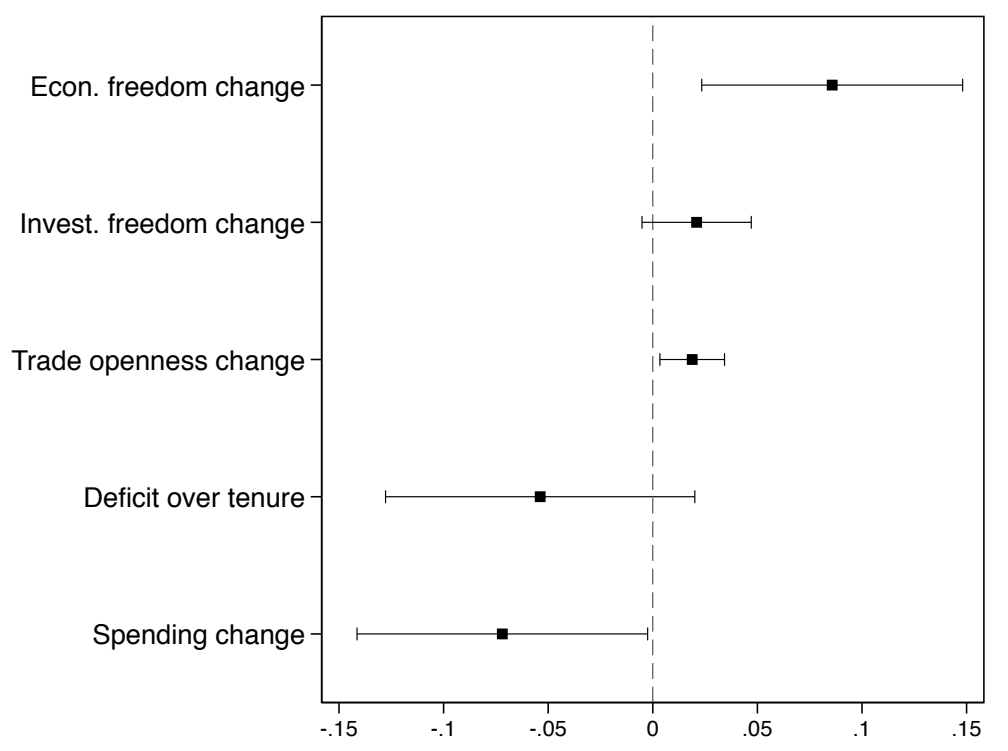

Figure 1: Robustness Analyses, Selected Coefficients. The figure plots selected coefficients and their confidence intervals, estimated in five separate probit regression models each, fully reported in Table 6. 


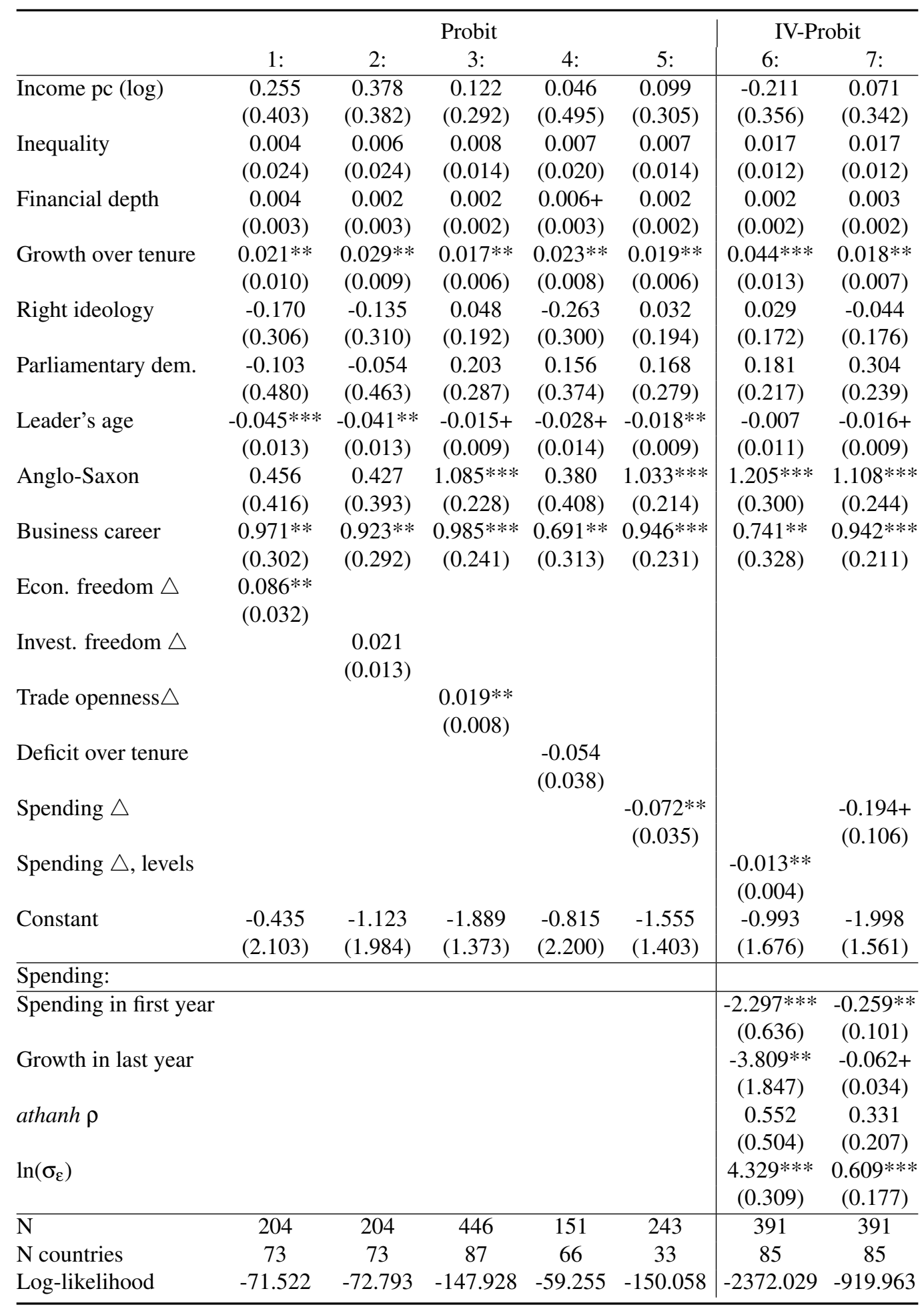

Table 6: Policies in Office and Business Careers of Former Leaders: Robustness Note: All estimations exclude leaders who retired, went into exile, were arrested or jailed after leaving office. The choice of business occupation is compared with other "active pursuits". Significant at $+p<0.10, * * p<0.05$, $* * * \mathrm{p}<0.01$. 


\begin{tabular}{|c|c|c|c|c|c|}
\hline & \multicolumn{2}{|c|}{ Inequality } & \multicolumn{2}{|c|}{ Compensation } & \multirow{2}{*}{$\begin{array}{c}\text { WVS } \\
5:\end{array}$} \\
\hline & 1: & 2: & 3: & 4: & \\
\hline \multirow[t]{2}{*}{ Income pc $(\log )$} & -0.245 & -0.193 & 0.036 & 0.024 & 0.229 \\
\hline & $(0.439)$ & $(0.427)$ & $(0.307)$ & $(0.301)$ & $(0.507)$ \\
\hline \multirow[t]{2}{*}{ Financial depth } & 0.006 & 0.004 & 0.001 & 0.001 & 0.001 \\
\hline & $(0.004)$ & $(0.003)$ & $(0.003)$ & $(0.003)$ & $(0.004)$ \\
\hline \multirow[t]{2}{*}{ Parliamentary dem. } & $1.040 * *$ & 0.053 & 0.231 & 0.298 & 0.314 \\
\hline & $(0.501)$ & $(0.241)$ & $(0.247)$ & $(0.295)$ & $(0.353)$ \\
\hline \multirow[t]{2}{*}{ Anglo-Saxon } & -0.171 & $1.051 * * *$ & $1.114 * * *$ & $1.244 * * *$ & \\
\hline & $(0.520)$ & $(0.241)$ & $(0.177)$ & $(0.300)$ & \\
\hline \multirow[t]{2}{*}{ CEO compensation } & $0.038+$ & $0.056 * *$ & & & 0.008 \\
\hline & $(0.021)$ & $(0.022)$ & & & $(0.033)$ \\
\hline \multirow[t]{2}{*}{ Inequality } & & & 0.009 & 0.010 & \\
\hline & & & $(0.013)$ & $(0.015)$ & \\
\hline Income of the top 10 share & $\begin{array}{l}0.055+ \\
(0.030)\end{array}$ & & & & \\
\hline Capital share & & $\begin{array}{c}-0.537 \\
(0.699)\end{array}$ & & & \\
\hline CEO pay, 3-year average & & & $\begin{array}{c}0.050 * * \\
(0.018)\end{array}$ & & \\
\hline CEO pay, ExecuComp & & & & $\begin{array}{c}0.037 \\
(0.026)\end{array}$ & \\
\hline \multirow[t]{2}{*}{ Right ideology } & & & & & -0.260 \\
\hline & & & & & $(0.301)$ \\
\hline \multirow[t]{2}{*}{ Years in politics } & & & & & -0.017 \\
\hline & & & & & $(0.010)$ \\
\hline \multirow[t]{2}{*}{ Business career } & & & & & 0.311 \\
\hline & & & & & $(0.363)$ \\
\hline \multirow[t]{2}{*}{ Ex finance minister } & & & & & 0.302 \\
\hline & & & & & $(0.330)$ \\
\hline \multirow[t]{2}{*}{ Economics degree } & & & & & -0.176 \\
\hline & & & & & $(0.303)$ \\
\hline \multirow[t]{2}{*}{ Leader's age } & & & & & -0.011 \\
\hline & & & & & $(0.016)$ \\
\hline \multirow[t]{2}{*}{ Growth over tenure } & & & & & $0.029 * *$ \\
\hline & & & & & $(0.014)$ \\
\hline \multirow[t]{2}{*}{ Income equality, WVS } & & & & & -0.035 \\
\hline & & & & & $(0.155)$ \\
\hline \multirow[t]{2}{*}{ Private business, WVS } & & & & & $0.357+$ \\
\hline & & & & & $(0.186)$ \\
\hline \multirow[t]{2}{*}{ Wealth accumulation, WVS } & & & & & 0.146 \\
\hline & & & & & $(0.241)$ \\
\hline \multirow[t]{2}{*}{ Constant } & -2.977 & -0.704 & $-2.295+$ & -2.212 & -4.629 \\
\hline & $(1.951)$ & $(1.792)$ & $(1.331)$ & $(1.358)$ & $(2.876)$ \\
\hline $\mathrm{N}$ & 137 & 355 & 427 & 275 & 171 \\
\hline $\mathrm{N}$ countries & 56 & 68 & 87 & 84 & 46 \\
\hline Log-likelihood & -54.250 & -124.867 & -152.941 & -110.654 & -58.260 \\
\hline
\end{tabular}

Table 7: Inequality, CEO Pay, and Cultural Norms: Robustness Note: All estimations exclude leaders who retired, went into exile, were arrested or jailed after leaving office. The choice of business occupation is compared with other "active pursuits". Significant at $+\mathrm{p}<0.10, * * \mathrm{p}<0.05, * * * \mathrm{p}<0.01$. 


\begin{tabular}{|c|c|c|c|c|c|c|c|c|c|}
\hline & \multicolumn{3}{|c|}{ All house } & \multicolumn{3}{|c|}{ Polarization } & \multicolumn{3}{|c|}{ Govt fractionalization } \\
\hline & 1: & 2: & 3: & 4: & 5: & 6: & $7:$ & 8: & 9: \\
\hline Income pc (log) & $\begin{array}{l}-0.084 \\
(0.309)\end{array}$ & $\begin{array}{l}-0.086 \\
(0.311)\end{array}$ & $\begin{array}{l}-0.129 \\
(0.316)\end{array}$ & $\begin{array}{l}-0.038 \\
(0.326)\end{array}$ & $\begin{array}{l}-0.036 \\
(0.320)\end{array}$ & $\begin{array}{l}-0.086 \\
(0.327)\end{array}$ & $\begin{array}{l}-0.046 \\
(0.286)\end{array}$ & $\begin{array}{l}-0.036 \\
(0.291)\end{array}$ & $\begin{array}{l}-0.087 \\
(0.290)\end{array}$ \\
\hline Financial depth & $\begin{array}{c}0.006 * * \\
(0.003)\end{array}$ & $\begin{array}{c}0.006 * * \\
(0.003)\end{array}$ & $\begin{array}{c}0.007 * * \\
(0.003)\end{array}$ & $\begin{array}{c}0.007 * * \\
(0.003)\end{array}$ & $\begin{array}{c}0.007 * * \\
(0.003)\end{array}$ & $\begin{array}{c}0.008 * * \\
(0.003)\end{array}$ & $\begin{array}{l}0.004+ \\
(0.002)\end{array}$ & $\begin{array}{l}0.004+ \\
(0.002)\end{array}$ & $\begin{array}{l}0.004+ \\
(0.002)\end{array}$ \\
\hline Inequality & $\begin{array}{c}0.008 \\
(0.016)\end{array}$ & $\begin{array}{c}0.007 \\
(0.016)\end{array}$ & $\begin{array}{c}0.007 \\
(0.016)\end{array}$ & $\begin{array}{c}0.006 \\
(0.016)\end{array}$ & $\begin{array}{c}0.007 \\
(0.016)\end{array}$ & $\begin{array}{c}0.006 \\
(0.016)\end{array}$ & $\begin{array}{c}0.007 \\
(0.015)\end{array}$ & $\begin{array}{c}0.007 \\
(0.015)\end{array}$ & $\begin{array}{c}0.007 \\
(0.015)\end{array}$ \\
\hline Growth over tenure & $\begin{array}{c}0.033 * * * \\
(0.009)\end{array}$ & $\begin{array}{c}0.035 * * * \\
(0.009)\end{array}$ & $\begin{array}{c}0.040 * * \\
(0.013)\end{array}$ & $\begin{array}{c}0.033 * * * \\
(0.009)\end{array}$ & $\begin{array}{c}0.030 * * \\
(0.011)\end{array}$ & $\begin{array}{c}0.032 * * \\
(0.012)\end{array}$ & $\begin{array}{c}0.033^{* * * *} \\
(0.009)\end{array}$ & $\begin{array}{c}0.031 * * \\
(0.012)\end{array}$ & $\begin{array}{c}0.044 * * \\
(0.014)\end{array}$ \\
\hline Anglo-Saxon & $\begin{array}{c}1.202 * * * \\
(0.274)\end{array}$ & $\begin{array}{c}1.203 * * * \\
(0.276)\end{array}$ & $\begin{array}{c}1.192 * * * \\
(0.275)\end{array}$ & $\begin{array}{c}1.104 * * * \\
(0.245)\end{array}$ & $\begin{array}{c}1.098 * * * \\
(0.230)\end{array}$ & $\begin{array}{c}1.127 * * * \\
(0.236)\end{array}$ & $\begin{array}{c}1.248 * * * \\
(0.236)\end{array}$ & $\begin{array}{c}1.243 * * * \\
(0.233)\end{array}$ & $\begin{array}{c}1.260 * * * \\
(0.229)\end{array}$ \\
\hline Right ideology & $\begin{array}{c}-0.174 \\
(0.243)\end{array}$ & $\begin{array}{l}-0.173 \\
(0.242)\end{array}$ & $\begin{array}{c}-0.184 \\
(0.242)\end{array}$ & $\begin{array}{c}-0.198 \\
(0.255)\end{array}$ & $\begin{array}{c}-0.199 \\
(0.254)\end{array}$ & $\begin{array}{c}-0.206 \\
(0.253)\end{array}$ & $\begin{array}{c}-0.142 \\
(0.229)\end{array}$ & $\begin{array}{c}-0.143 \\
(0.228)\end{array}$ & $\begin{array}{c}-0.153 \\
(0.229)\end{array}$ \\
\hline Parliamentary dem. & $\begin{array}{l}-0.009 \\
(0.308)\end{array}$ & $\begin{array}{c}-0.008 \\
(0.309)\end{array}$ & $\begin{array}{c}0.011 \\
(0.315)\end{array}$ & $\begin{array}{c}-0.084 \\
(0.319)\end{array}$ & $\begin{array}{l}-0.070 \\
(0.312)\end{array}$ & $\begin{array}{l}-0.089 \\
(0.317)\end{array}$ & $\begin{array}{c}-0.036 \\
(0.296)\end{array}$ & $\begin{array}{l}-0.046 \\
(0.290)\end{array}$ & $\begin{array}{c}-0.014 \\
(0.299)\end{array}$ \\
\hline Leader's age & $\begin{array}{c}-0.021 * * \\
(0.010)\end{array}$ & $\begin{array}{c}-0.021 * * \\
(0.010)\end{array}$ & $\begin{array}{c}-0.022 * * \\
(0.010)\end{array}$ & $\begin{array}{c}-0.028^{* *} \\
(0.010)\end{array}$ & $\begin{array}{c}-0.028 * * \\
(0.010)\end{array}$ & $\begin{array}{c}-0.028 * * \\
(0.010)\end{array}$ & $\begin{array}{c}-0.021 * * \\
(0.009)\end{array}$ & $\begin{array}{c}-0.021 * * \\
(0.009)\end{array}$ & $\begin{array}{c}-0.021 * * \\
(0.009)\end{array}$ \\
\hline Business career & $\begin{array}{c}1.051 * * * \\
(0.251)\end{array}$ & $\begin{array}{c}1.050 * * * \\
(0.249)\end{array}$ & $\begin{array}{c}1.057 * * * \\
(0.252)\end{array}$ & $\begin{array}{c}1.071 * * * \\
(0.284)\end{array}$ & $\begin{array}{c}1.042 * * * \\
(0.278)\end{array}$ & $\begin{array}{c}1.074 * * * \\
(0.284)\end{array}$ & $\begin{array}{c}0.974 * * * \\
(0.252)\end{array}$ & $\begin{array}{c}0.970 * * * \\
(0.249)\end{array}$ & $\begin{array}{c}0.975^{* * *} \\
(0.251)\end{array}$ \\
\hline Spending $\triangle$, levels & $\begin{array}{l}-0.007 \\
(0.004)\end{array}$ & $\begin{array}{c}-0.008 * * \\
(0.003)\end{array}$ & $\begin{array}{l}-0.002 \\
(0.006)\end{array}$ & $\begin{array}{c}-0.006^{* *} \\
(0.002)\end{array}$ & $\begin{array}{c}-0.007 * * \\
(0.003)\end{array}$ & $\begin{array}{c}-0.003^{* *} \\
(0.001)\end{array}$ & $\begin{array}{c}-0.007 * * \\
(0.003)\end{array}$ & $\begin{array}{c}-0.006 * * \\
(0.003)\end{array}$ & $\begin{array}{c}-0.005^{*} * \\
(0.002)\end{array}$ \\
\hline Allhouse & $\begin{array}{c}0.377 \\
(0.246)\end{array}$ & $\begin{array}{c}0.368 \\
(0.231)\end{array}$ & $\begin{array}{c}0.413 \\
(0.259)\end{array}$ & & & & & & \\
\hline Allhouse $\times$ Spending & $\begin{array}{l}-0.002 \\
(0.004)\end{array}$ & & $\begin{array}{c}-0.004 \\
(0.006)\end{array}$ & & & & & & \\
\hline Allhouse $\times$ Growth & & $\begin{array}{l}-0.005 \\
(0.013)\end{array}$ & $\begin{array}{l}-0.001 \\
(0.022)\end{array}$ & & & & & & \\
\hline Growth $\times$ Spending & & & $\begin{array}{l}-0.000 \\
(0.000)\end{array}$ & & & $\begin{array}{c}-0.000 * * \\
(0.000)\end{array}$ & & & $\begin{array}{c}-0.000 * * \\
(0.000)\end{array}$ \\
\hline Allhouse $\times$ Growth $\times$ Spending & & & $\begin{array}{c}0.000 \\
(0.000)\end{array}$ & & & & & & \\
\hline Polarization & & & & $\begin{array}{c}0.062 \\
(0.151)\end{array}$ & $\begin{array}{c}-0.067 \\
(0.148)\end{array}$ & $\begin{array}{c}0.033 \\
(0.176)\end{array}$ & & & \\
\hline Polariz. $\times$ Spending & & & & $\begin{array}{l}-0.003 \\
(0.004)\end{array}$ & & $\begin{array}{l}-0.007 \\
(0.007)\end{array}$ & & & \\
\hline Polariz. $\times$ Growth & & & & & $\begin{array}{c}0.004 \\
(0.009)\end{array}$ & $\begin{array}{c}0.009 \\
(0.014)\end{array}$ & & & \\
\hline Polariz. $\times$ Growth $\times$ Spending & & & & & & $\begin{array}{c}0.000 \\
(0.000)\end{array}$ & & & \\
\hline Govt. fractionalization & & & & & & & $\begin{array}{c}0.039 \\
(0.389)\end{array}$ & $\begin{array}{c}0.111 \\
(0.428)\end{array}$ & $\begin{array}{c}0.191 \\
(0.475)\end{array}$ \\
\hline Frac. $\times$ Spending & & & & & & & $\begin{array}{c}0.005 \\
(0.009)\end{array}$ & & $\begin{array}{c}0.002 \\
(0.013)\end{array}$ \\
\hline Frac. $\times$ Growth & & & & & & & & $\begin{array}{c}0.006 \\
(0.025)\end{array}$ & $\begin{array}{c}-0.024 \\
(0.032)\end{array}$ \\
\hline Frac. $\times$ Growth $\times$ Spending & & & & & & & & & $\begin{array}{c}0.000 \\
(0.000)\end{array}$ \\
\hline Constant & $\begin{array}{c}-0.782 \\
(1.444)\end{array}$ & $\begin{array}{c}-0.769 \\
(1.431)\end{array}$ & $\begin{array}{c}-0.715 \\
(1.481)\end{array}$ & $\begin{array}{c}-0.439 \\
(1.493)\end{array}$ & $\begin{array}{c}-0.368 \\
(1.500)\end{array}$ & $\begin{array}{c}-0.268 \\
(1.493)\end{array}$ & $\begin{array}{c}-0.714 \\
(1.372)\end{array}$ & $\begin{array}{c}-0.756 \\
(1.385)\end{array}$ & $\begin{array}{l}-0.618 \\
(1.384)\end{array}$ \\
\hline $\bar{N}$ & 378 & 378 & 378 & 343 & 343 & 343 & 379 & 379 & 379 \\
\hline $\mathrm{N}$ countries & 85 & 85 & 85 & 86 & 86 & 86 & 87 & 87 & 87 \\
\hline Log-likelihood & -114.726 & -114.749 & -114.126 & -104.301 & -104.564 & -103.131 & -117.836 & -117.936 & -117.333 \\
\hline
\end{tabular}

Table 8: Policies and Constraints in Office: Robustness Note: All estimations exclude leaders who retired, went into exile, were arrested or jailed after leaving office. The choice of business occupation is compared with other "active pursuits". Significant at $+\mathrm{p}<0.10,{ }^{* *} \mathrm{p}<0.05,{ }^{* * *} \mathrm{p}<0.01$. 